\title{
Respiratory RNA Viruses: How to Be Prepared for an Encounter with New Pandemic Virus Strains
}

\author{
S. V. Chepur ${ }^{a, ~ *, ~ N . ~ N . ~ P l u z h n i k o v ~}{ }^{a}$, O. V. Chubar $^{a}$, L. S. Bakulina ${ }^{b}$, I. V. Litvinenko ${ }^{c}$, V. A. Makarov ${ }^{d}$, \\ A. S. Gogolevsky ${ }^{a}$, V. A. Myasnikov ${ }^{a}$, I. A. Myasnikova ${ }^{a}$, and R. I. Al-Shehadat ${ }^{a}$ \\ ${ }^{a}$ State Scientific Research Test Institute of Military Medicine of the Ministry of Defense of the Russian Federation, \\ St. Petersburg, 195043 Russia \\ ${ }^{b}$ Burdenko Voronezh State Medical University, Voronezh, 394036 Russia \\ ${ }^{c}$ Kirov Military Medical Academy, St. Petersburg, 194044 Russia \\ ${ }^{d}$ Fundamentals of Biotechnology Federal Research Center, Moscow, 119071 Russia \\ *e-mail:gniiivm_2@mail.ru \\ Received April 20, 2020; revised April 20, 2020; accepted April 20, 2020
}

\begin{abstract}
The characteristics of the biology of influenza viruses and coronavirus that determine the implementation of the infectious process are presented. With provision for pathogenesis of infection possible effects of serine proteinase inhibitors, heparin, and inhibitors of heparan sulfate receptors in the prevention of cell contamination by viruses are examined. It has been determined that chelators of metals of variable valency and antioxidants should be used for the reduction of replicative activity of viruses and anti-inflammatory therapy. The possibility of a $\mathrm{pH}$-dependent impairment of glycosylation of cellular and viral proteins was traced for chloroquine and its derivatives. The use of low-toxicity drugs as part of adjunct therapy increases the effectiveness of synthetic antiviral drugs and interferons and ensures the safety of baseline therapy.
\end{abstract}

Keywords: RNA viruses, chloroquine, inhibitors of serine proteinases, cell contamination prevention

DOI: $10.1134 / \mathrm{S} 207908642102002 \mathrm{X}$

\section{INTRODUCTION}

Humanity is faced with the emergence of new, previously unknown strains of virulent respiratory viruses that threaten the death of a large number of people with mystical regularity. Influenza viruses and coronaviruses, which have been in contact with people since ancient times, pose a particular epidemic/pandemic danger.

It is believed that the first major outbreak of respiratory infection clinically similar to influenza was described in detail by Hippocrates as early as 412 BC as a contagious "Perinthian cough" (Kuszewski and Brydak, 2000; Pappas, 2008). The next detailed writeup of influenza-like epidemic respiratory disease known as the "peasant fever" of 1173-1174 was only compiled 1500 years later in England (Potter, 2001). The first influenza pandemic is well-defined in 1580 (Potter, 2001; Daly et al., 2007). At the same time, in the 16th century, this infectious disaster was called "influenza" (influence, from Latin), since this disease at that time was considered a bad "influence of heaven" (Broxmeyer, 2006). Since then, 31 influenza pandemics have been recorded, three of which were observed in the 20th century and one took place in the 21st century (Kilbourne, 2006; Daly et al., 2007; AlMuharrmi, 2010) (Table 1).
Although a targeted search for pathogens capable of causing epidemics/pandemics of acute respiratory infections began at the end of the 19th century (Pfeiffer, 1893; Olitsky and Gates, 1921a, 1921b), the type-A influenza virus Mixovirus influenza was isolated only in 1933 (Smith et al., 1933). B- and C-types of influenza viruses were identified in 1940 and 1947, respectively (Francis, 1940; Taylor, 1949), and only in 2011 the type-D influenza virus was isolated and characterized (Hause et al., 2013; Ducatez et al., 2015).

Coronaviruses are also characterized by blanket distribution (Suzuki et al., 2005; Koetz et al., 2006; Sloots et al., 2006; Zhao et al., 2008) and seem to have been in contact with humans since ancient times (Wertheim et al., 2013). Until recently, it was believed that coronavirus infections, which are manifested only by symptoms of an ordinary cold, caused 15 to $35 \%$ of seasonal acute respiratory infections. Children get sick five to seven times more often than adults (McIntosh et al., 1970; Callow et al., 1990; Holmes, 2001). In humans, acute respiratory infections are caused by two types of $\alpha$-coronaviruses (229E and NL63) and two types of $\beta$-coronaviruses (OC43 and HKU1) (Gaunt et al., 2010). However, veterinarians have long known that coronaviruses can cause fatal respiratory and intestinal infections in animals (Pensaert, 1999). As a 
Table 1. Influenza pandemics of the last century

\begin{tabular}{l|c|c|c}
\hline Pandemic (name) & Years & Strain & $\begin{array}{c}\text { Number of deaths } \\
\text { (million people) }\end{array}$ \\
\hline Spanish flu & $1918-1920$ & H1N1 & $40-50$ \\
Asian flu & $1957-1958$ & H2N2 & $1-2$ \\
Hong Kong flu & $1968-1970$ & H3N2 & $0.5-2$ \\
Swine flu & $2009-2010$ & H1N1 & 0.5 \\
\hline
\end{tabular}

potential biological threat, coronaviruses have posed a real challenge to modern medicine. In recent decades, new pandemic strains of coronaviruses that are extremely dangerous to humans have often emerged: severe acute respiratory syndrome coronavirus (SARS-CoV, 2002/2003), Middle East respiratory syndrome coronavirus (MERS-CoV, 2012), and the novel type of pneumonia coronavirus (COVID-19, 2019/2020); they are capable of causing severe, often unfavorable, bronchiolitis and pneumonias (Cherry, 2004; Ramadan and Shaib, 2019; Hui et al., 2020).

Human coronaviruses were first isolated from patients with acute respiratory diseases in 1965 (Hamre and Procknow, 1966; Tyrrell and Bynoe, 1966). Electron microscopy showed them to have a coronal structure feature, what is subsequently reflected in their name (Tyrrell et al., 1975). Since then coronaviruses attracted little attention from researchers for nearly three decades (before the emergence of pandemic strains).

It is clear that pandemics of respiratory viral infections have plagued humankind in the past, and there is no reason to believe that this will not happen in the future. The time and place of the emergence of new pandemics and virulence of pandemic virus strains cannot be predicted.

\section{BIOLOGICAL CHARACTERISTICS OF INFLUENZA VIRUSES AND CORONAVIRUSES}

Influenza viruses belong to the family of orthomyxoviruses (Orhtomyxoviridae, RNA viruses with a segmented genome) and are divided into four monotypic genera: influenza-A viruses (Alphainfluenza virus), influenza-B viruses (Betainfluenza virus), influenza-C viruses (Gammainfluenza virus), and influenza-D viruses (Deltainfluenza virus), each of them is represented by only one type of virus of the same name. It is believed that only influenza-A viruses have pandemic potential (Bouvier and Palese, 2008; Spickler, 2016; King et al., 2018). Influenza-A viruses are subdivided into subtypes with respect to the antigenic properties of hemagglutinin HA (the glycoprotein of the virion envelope, which ensures the recognition of target cells and the binding of viral particles to terminal residues of sialic acids of the glycoproteins of the plasma membrane of epithelial cells) and neur- aminidase NA (exo- $\alpha$-sialidase, which catalyzes the cleavage of the glycosidic bonds of the terminal residues of sialic acids of oligosaccharides, glycoproteins, glycolipids and thereby allows the release of daughter influenza virions from infected cells).

In total, there are 18 known serotypes of hemagglutinin $(\mathrm{H} 1-\mathrm{H} 18)$ and 11 identified serotypes of neuraminidase (N1-N11); therefore, it is theoretically possible to form 198 different combinations of these proteins, subtypes of the influenza-A virus (Skehel, 2009; Tong et al., 2013; Quan et al., 2016; Kosik and Yewdell, 2019; Zhao et al., 2019), of which more than 120 combinations have been identified in nature (Tsai and Chen, 2011; Rejmanek et al., 2015).

Eight negatively polar segments of the RNA genome of the influenza virus encode at least ten structural and nine regulatory proteins (Varga et al., 2011; Muramoto et al., 2013; Hutchinson et al., 2014; Vasin et al., 2014). There is some uncertainty about the proteome of influenza-A viruses due to the fact that, unlike most RNA viruses, the transcription and translation of their genome occurs in the nucleus, not in the cytoplasm of infected cells. This allows influenza-A viruses (Fig. 1) to exploit cellular splicing machinery to generate splice variants of viral mRNAs. In addition, influenza-A viruses seem to use alternative open reading frames to expand their proteome.

Most viral proteins are localized within the viral lipid envelope; only HA and NA, in a molar ratio of about 10 : 1 (Mitnaul et al., 2000), and the M2 protein embedded in the virion envelope carry antigenic determinants available for the action of immune antibodies (Kosik and Yewdell, 2019). HA and NA molecules are extensively glycosylated proteins, which ensures their functional activity and aberration from protective immune responses via screening of antigenic determinants (Kim et al., 2018; York et al., 2019).

Unlike influenza viruses, coronaviruses are enveloped RNA viruses (with nonsegmented, positivepolar RNA) of Nidovirales order, Coronaviridae family, Orthocoronavirinae subfamily (Fehr and Perlman, 2015). Coronaviral virions have spherical shape with characteristic clavate projections (Neuman et al., 2006; Barcena et al., 2009) (Fig. 2). The virion envelope is formed by a lipid bilayer where S-, M-, and Eproteins are fixed (Lai and Cavanagh, 1997; De Haan and Rottier, 2005).

Spike proteins (SPs) function as abundantly glycosylated trimeric complexes (Zheng et al., 2017; Parsons et al., 2019), ensure the interaction of the virion with epithelial cell receptors and the subsequent internalization of the viral genome ( $\mathrm{Li}, 2016)$.

Membrane proteins (MPs) function as a dimer with a glycosylated N-terminal ectodomain (Nal et al., 2005) and can accept two different conformational states. The conformers of this glycoprotein determine the assembly and shape of the viral particle (Neuman et al., 2011). 


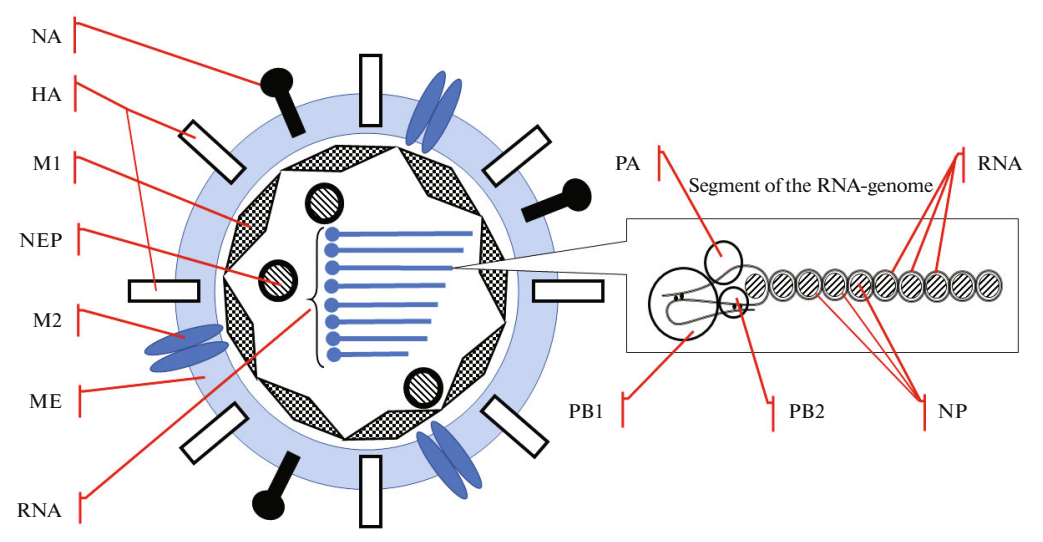

Fig. 1. Structural elements of the type A influenza virus. HA-hemagglutinin (trimer), NA-neuraminidase (tetramer), M1matrix protein 1, M2-matrix protein 2, ME-phospholipid membrane, NEP-nuclear exporter protein, RNA-negative-strand RNA in ribonucleoprotein segments, NP-nucleocapsid protein, $\mathrm{PA}$-acidic polymerase protein, $\mathrm{PB} 1$-basic polymerase protein $1, \mathrm{~PB} 2$ - basic polymerase protein 2 .

Envelope proteins (EPs) are transmembrane proteins that are found in small quantities and perform several functions: virion assembly, envelope formation, and the release of a viral particle from the cell. There are indirect indications that they are glycoproteins (Schoeman and Fielding, 2019).

Nucleoproteins (NPs) are the only proteins found inside the virion. They enable the packaging of the viral genome (McBride et al., 2014).

It is noteworthy that, as in the case of influenza-A viruses, the envelope proteins of coronaviruses are glycoproteins.

The process of cell penetration by the influenza virus consists of several stages. A critical moment in the life cycle of the influenza virus is the recognition of specific cellular receptors, glycoproteins or glycolipids. The glycan contains the terminal $\alpha 2,6$ - or $\alpha 2,3-$ sialic acid (Leung et al., 2012; Byrd-Leotis et al., 2017). The attachment of the HA virion to sialylated glycoproteins and glycolipids of the plasma membrane of epithelial cells initiates various endocytosis mechanisms. This rapidly leads to the formation of endosomes, where each of them contains a viral particle (Chardonnet and Dales, 1970; Matlin et al., 1981; Kartenbeck et al., 1989; Rojek et al., 2008; Nanbo et al., 2010; Watanabe et al., 2010; Boulant et al., 2015).

The next stage of internalization, the release of the viral genome (RNA segments) into the cell cytosol, depends on the activity of $\mathrm{Na}^{+} / \mathrm{K}^{+}$-ATPase, which is localized in the endosomal membrane and functions as a proton pump.

The $\mathrm{Na}^{+} / \mathrm{K}^{+}$-ATPase results in acidification of the medium inside endosomes/lysosomes to a $\mathrm{pH}$ of 5.0 (Cain et al., 1989). Acidification of the intraendosomal medium, i.e., the accumulation of $\mathrm{H}^{+}$protons in the endosome content, makes it possible to realize the protonophore potential of the tetramers of the M2 protein of the viral-particle envelope (Sugrue and Hay, 1991; Pinto et al., 1992; Manzoor et al., 2017). The penetration of hydrogen ions into the viral particle mediates conformational changes and decomposition of the structural components of the virion envelope and, ultimately, leads to labilization of its genome (Shibata et al., 1983; Yoshimura and Ohnishi, 1984). However, the fusion of the envelope of the viral particle and the endosomal membrane, which ensures the release of the RNA genome of the virus into the cell cytosol, is possible only with the participation of the HA virion, which undergoes preliminary proteolytic processing by serine (secretory trypsin-like) proteinases (Klenk, 1975; Lazarowitz and Choppin, 1975; Tashiro et al., 1987; Steinhauer, 1999; Kido et al., 2009).

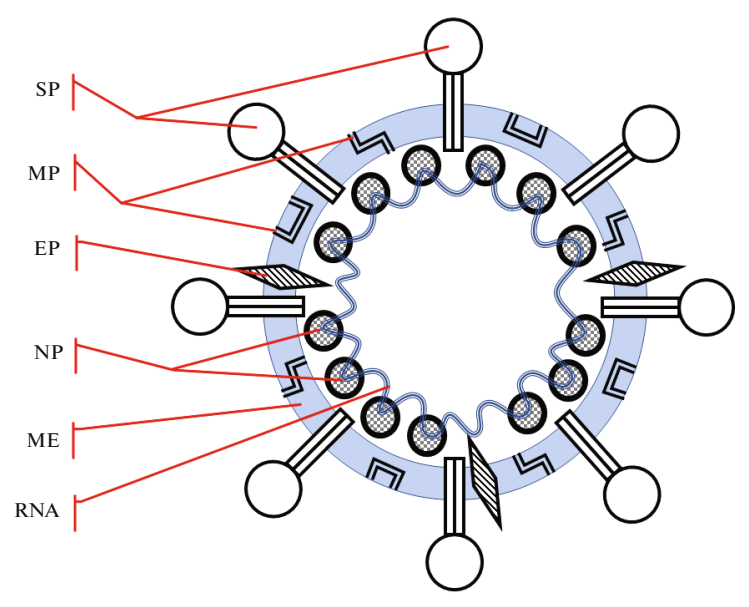

Fig. 2. Structural elements of the coronavirus virion. SP$\mathrm{S}$-protein (trimer), MP-dimer of the membrane protein in various conformations, EP-transmembrane envelope protein, ME-phospholipid membrane, RNA-positivestrand RNA, NP-nucleocapsid protein. 
Translocation of RNA segments of the influenzavirus genome from the cytosol into the cell nucleus is necessary for their replication. During this process viral mRNAs of the nucleus enter the cytosol for consequent synthesis of proteins of viral particles. Selfassembly of virions occurs on the apical part of the plasma membrane of epithelial cells, where HA and NA molecules are concentrated (Samji, 2009; Dou et al., 2018).

The internalization process of coronaviruses is determined by functional activity of the virion SP envelope. The coronaviral SP is strongly glycosylated structure that enables the fixation of viral particles on the plasma membrane of epithelial cells and the subsequent release of their RNA genome into the cell cytosol (Li, 2016; Watanabe et al., 2020). Each SP has two receptor-binding domains localized on its $\mathrm{S} 1$ subunit; they are capable of interacting either with specific proteins or with sialoglycans of epithelial cells ( $\mathrm{Li}, 2012$; Shahwan et al., 2013; Hulswit et al., 2019). For example, MERS-CoV preferentially binds to $\alpha 2,3$-linked sialic acid (to a lesser extent to $\alpha 2,6$-linked sialic acid) (Li et al., 2017). The COVID-19 viruses appear to have a similar affinity for $\alpha 2,3$-sialic acid conjugates.

Internalization of the viral genome can occur either through endocytosis of the virion (the process is largely similar to the process of internalization of influenza viruses) or by fusion of the coronavirus envelope and the plasma membrane of the epithelial cell without endosome formation (directly on the plasma membrane). In any case, the release of the RNA genome of the virus into the cytosol of the cell is preceded by proteolytic cleavage of the $\mathrm{S} 1$ subunit and modulation of the $\mathrm{S} 2$ subunit of SP by serine proteases (Bosch et al., 2003; Belouzard et al., 2009; Simmons et al., 2013; Heurich et al., 2014; Zumla et al., 2016).

In the cytoplasm of the epithelial cell, the RNA genome of the virus functions as mRNA, when the replication-transcriptional complex also enables replication of the RNA genome and the mRNA synthesis of structural proteins of the viral particle (Sola et al., 2015; Nakagawa et al., 2016). Following posttranslational glycosylation in the Golgi apparatus cisterns newly synthesized coronavirus proteins ( $\mathrm{Nal}$ et al., 2005; Tseng et al., 2010) enter the cytosol and provide self-assembly of viral particles, which subsequently migrate to the cell membrane as part of the vesicles and leave the cell through exocytosis (Fehr and Perlman, 2015; Lim et al., 2016).

Due to the importance of serine proteinases, glycoproteins, and glycolipids in the life cycle of influenza viruses and coronaviruses, it can be assumed that factors modulating the glycosylation profile of proteins and lipids of epithelial cells and viruses and controlling the activity of serine proteinases on the epithelial lining of the respiratory tract can significantly limit the virulence of influenza viruses and coronaviruses.

\section{GENETIC EVOLUTION OF INFLUENZA-A VIRUSES AND CORONAVIRUSES}

Influenza viruses, when circulating in natural reservoirs, are characterized by high genetic variability, which is manifested in the formation of quasi-subtypes (immunologically distinct antigenic variants) of A viruses (Barbezange et al., 2018). This biological feature, antigenic drift (Taubenberger and Kash, 2010), is stipulated by the fact that the RNA-dependent RNA polymerase of influenza viruses does not have an active correction site (Steinhauer et al., 1989; Cheung et al., 2014). This leads to a high frequency of point mutations in the course of RNA genome replication (300 times more often than during the replication of the bacterial DNA genome) (Drake, 1993). Their other distinguishing characteristic is a high mutational tolerance of the envelope glycoproteins of viral particles, i.e., the ability of HA and NA to maintain functional activity with significant changes in a primary structure of the polypeptide chain (Thyagarajan and Bloom, 2014; Visher et al., 2016).

An important and widespread phenomenon in the evolution of influenza-A viruses is antigenic shift (Holmes, 2005; Dugan et al., 2008). Antigenic shift is the exchange of RNA segments of the viral genome encoding the structure of HA and/or NA in cases of simultaneous infection of the cell with several strains of the influenza-A virus (Taubenberger and Kash, 2010). It is antigenic shift that allows new subtypes of the type-A influenza virus to overcome interspecies barriers (Scholtissek et al., 1978; Garten et al., 2009).

Unlike other RNA viruses, RNA-dependent RNA polymerase, which has 3 '-exonuclease correcting activity, is involved in the replication of the coronavirus genome (Smith et al., 2014). In order to evade the mechanisms of the immunoresponse of the human body and to preserve the genotype in the Homo sapiens population, as shown by the example of the $\mathrm{HCoV}-$ OC43 strain, coronaviruses also maintain a state of antigenic drift (Ren et al., 2015). In addition, the coronaviral genome also evolves through RNA-RNA recombinations (Keck et al., 1988; Huang et al., 2016; Forni et al., 2017). Homologous RNA recombination is the redistribution of genetic material by means of the exchange of regions of the RNA genome of viruses under conditions of coinfection (Makino et al., 1986; Lai, 1990; Lai and Cavanagh, 1997). In addition to aberration of the host immunoresponse mechanisms, RNA recombination allows coronaviruses to change the virulence profile and tissue tropism and to overcome interspecific barriers (Haijema et al., 2003; Stavrinides and Guttman, 2004).

A high genetic and phenotypic variability of influenza-A viruses and coronaviruses is fraught with the acquisition of resistance by these pathogens to specific medical and prophylactic agents, as well as the sudden appearance of new virulent pandemic strains. 


\section{PANDEMIC OF RESPIRATORY VIRAL INFECTIONS AND THE PROBLEM OF PNEUMONIA}

The influenza pandemic of 1918-1920, the most fatal event in the history of mankind, carried away lives of more than 50 million people (Johnson and Mueller, 2002). Mortality during pandemics of influenza and coronaviruses is, to a large extent, associated with pneumonia (Morens et al., 2008; Metersky et al., 2012; Yin and Wunderink, 2018; Al-Baadani et al., 2019). Primary viral pneumonias are often complicated by bacterial coinfection, i.e., they turn into viralbacterial and bacterial pneumonias (Oswald et al., 1958; Bisno et al., 1971; Palacios et al., 2009; Gill et al., 2010; Martin-Loeches et al., 2011; Cilloniz et al., 2012). Therefore, there is a widespread opinion among infectious disease specialists that was formulated by Louis Cruvellier in 1919: "Si la grippe condamne, la surinfection exécute, a-ton dit avec raison" (Cruveilhier, 1919, 448 p.).

At the same time, the clinical picture of severe viral respiratory infections is often represented by a symptom complex of primary viral pneumonia. The emergence of primary viral pneumonia during respiratory viral infections is apparently associated with the copresentation of glycoproteins and glycolipids. They differ in the presence of glycans with terminal $\alpha 2,3$ linked sialic acid (which acts as a receptor for respiratory viruses), with the transmembrane serine proteinase TMPRSS2 (which proteolytically activates HA and SP of virions) on the plasma membranes of epithelial cells of alveoli and bronchioles (Ibricevic et al., 2006; Shinya et al., 2006; Kumlin et al., 2008; Bertram et al., 2010; Limburg et al., 2019; Tortorici et al., 2019).

The formation of a susceptibility to bacterial coinfection during respiratory viral pandemics is associated with many factors, such as

- a virus-induced dysbiotic state and impaired barrier function of the epithelial lining of the respiratory tract (Pittet et al., 2010; Ellis et al., 2015; NitaLazar et al., 2015; Hanada et al., 2018; Sencio et al., 2020);

- virus-induced dysfunction of the effector cells of the immune system (McNamee and Harmsen, 2006; Small et al., 2010; Ghoneim et al., 2013; Sun and Metzger, 2014) and the immunosuppressive activity of cytokines in relation to antibacterial immunity (van der Sluijs et al., 2004; Cao et al., 2014; Shepardson et al., 2019);

- virus-associated dysfunction of the alveolarcapillary barrier (McAuley et al., 2007; Henkel et al., 2010; Short et al., 2016; Kamal et al., 2017) and suppression of the activity of ion pumps that ensure the absorption of fluid from the lumen of the alveoli (Carlson et al., 2010; Peteranderl et al., 2016; Brand et al., 2018).
Pneumonia associated with respiratory viral infections is an independent factor in the severity of disease and mortality (Maruyama et al., 2016; Ishiguro et al., 2017). So, to a large extent, the main problem of severe viral infections, both in the past and the present, is a problem of viral, viral-bacterial, and secondary bacterial pneumonias.

\section{BASIS FOR DIRECTIONS OF PATHOGENETIC THERAPY}

The biology of influenza viruses and coronaviruses inevitably leads to the emergence of new pandemic strains, and their time of occurrence, genetic characteristics and antigenic properties cannot be predicted. That is, pandemics of new respiratory infections will always begin in the absence of specific immune prophylaxis and therapy for these infections. The latter predetermines the need for an early search and development of pathogenetic agents and methods for the prevention/therapy of respiratory viral infections in terms of biology of coronaviruses and influenza-A viruses.

The nature of RNA viruses suggests the effectiveness of systemic administration of interferon preparations (viferon, intron A, reaferon, etc.) for baseline nonspecific therapy for the infections caused by them, with allowance for the asthenization caused by medicines. The effectiveness of topical administration of interferon solutions is doubtful and can be considered in the presence of local symptoms (rhinitis, pharyngitis, etc.). The use of interferon inducers (amixin, cycloferon, neovir, etc.) involves the formation of secondary immunosuppression in 10-14 days, which can lead to reinfection in the ongoing epidemic period. The drugs of basic antiviral therapy also include targeted agents that affect the replication of the viral genome: oseltamivir, triazavirin, and ribavirinum, which is the strongest but also the most toxic of the drugs in this group. There are also targeted antiviral agents (lopinavir, ritonavir, nelfinavir) (Yamamoto et al., 2020). Antireplicative activity was traced for the purine derivative, isoprinosine, which is active against influenza-A and -B viruses.

Up-to-date knowledge about the nature of viruses and the formation of the infectious process makes it possible to consider the possibility of widespread use of pathogenetic therapy, the effectiveness of which has been traced in various studies.

It is known that serine proteinases are involved in the provision of internalization of coronaviruses and influenza-A viruses into epithelial cells (Simmons et al., 2013; Garten et al., 2015). The activity of trypsin-like proteinases tract largely depends on the activity of secretory inhibitors of leukoproteinases in the upper respiratory and on the surfactant in the lower regions (Kido et al., 2004). Thus, drugs that have the ability to induce the expression of inhibitors of secre- 
tory leukoproteinases and surfactant and their direct inhibitors can significantly inhibit the multicyclic replication of RNA viruses.

Quercetin has all these properties. In addition to its antioxidant effects, e.g., chelation of metals of variable valence (Gholampour and Saki, 2019), stimulation of the expression of antioxidant enzymes (Chen et al., 2017), a direct reduction of free radicals of fatty acid residues of phospholipids and oxidized forms of vitamin E (Chepur and et al., 2020; Ozgen et al., 2016), quercetin in the micromolar concentration range inhibits the activity of serine proteinases (Xue et al., 2017; Jo et al., 2019) and shields the active center of HA of the influenza-A virus (Wu et al., 2015), which gives it a wide range of antiviral effects (Zakaryan et al., 2017).

Trans-4-[[(2-amino-3,5-dibromophenyl)methyl]amino]cyclohexanol hydrochloride (as ambroxol or lazolvan) is also gaining attention as an antiviral adjunct (Yang et al., 2002; Yamaya et al., 2014). The spectrum of pharmacological activity of ambroxol, in addition to its mucolytic effect (Rogers, 2007), includes

- antibacterial and antibiofilm effects ( $\mathrm{Lu}$ et al., 2010; Li et al., 2011; Cabral-Romero et al., 2013; Cataldi et al., 2014);

- the ability to exhibit the activity of a chemical chaperone (Bendikov-Bar et al., 2013; Sanchez-Martinez et al., 2016), a modulator of surfactant secretion (Yang et al., 2002; Seifart et al., 2005), and to provide anti-inflammatory (Gibbs et al., al., 1999; Beeh et al., 2008; Gupta, 2010) and antioxidant action (Nowak et al., 1994; Stětinová et al., 2004);

- the ability to (respiratory organs) stimulate locally the secretion of immunoglobulins IgA and IgG (Yang et al., 2002) and to provide a local anesthetic effect (Kern and Weiser, 2015).

Ambroxol, which possesses the listed properties and is characterized by high bioavailability when administered perorally (Jauch et al., 1978), can be included in the list of drugs used to treat viral pneumonia.

Virus-induced oxidative stress plays a significant role in the pathogenesis of respiratory infections (Schwarz, 1996; Lin et al., 2006; Liu et al., 2017; Khomich et al., 2018). Xanthine oxidoreductase (XOR) plays a leading role in the formation of a symptom complex of manifestations and complications of virusassociated pneumonia. XOR is a cytosolic enzyme of purine catabolism (Frederiks and Vreeling-Sindelárová, 2002; Agarwal et al., 2011). Its activity rapidly increases under hypoxic conditions (Poss et al., 1996; Terada et al., 1997; Linder et al., 2003) and under the influence of pro-inflammatory mediators and cytokines (Page et al., 1998; Brandes et al., 1999). Under pathological conditions, XOR is released from cells into blood (the oxidase form of the enzyme predominates) (Spiekermann et al., 2003) and is fixed on the luminal surface of the plasma membrane of endo- theliocytes in the inflammation zone through physicochemical interaction with glycosaminoglycans (Rouquette et al., 1988; Akaike et al., 1990; Adachi et al., 1993). XOR, which is localized on the cytoplasmic membrane of endothelial cells, produces a superoxide radical anion during purine oxidation and can simultaneously reduce nitrite and nitrate anions to nitric oxide NO ${ }^{*}$ at another active site (Jansson et al., 2008; Cantu-Medellin and Kelley, 2013), i.e., it can recycle this vasodilating agent. The local production of the complex of prooxidants $\mathrm{O}_{2}^{-}, \mathrm{H}_{2} \mathrm{O}_{2}$, $\mathrm{NO}^{-}$and $\mathrm{ONOO}^{-}$ is potentially very dangerous, especially in the vascular bed of lungs. However, attempts to use the XOR inhibitor allopurinol (Pacher et al., 2006; George and Struthers, 2009) as a therapeutic agent for pneumonia induced by type-A influenza virus in the range of daily doses of $5-50 \mathrm{mg} / \mathrm{kg}$ were unsuccessful. Allopurinol had no effect on the course and the outcomes of viral infection (Dolganova and Sharonov, 1997), because the NADH oxidase and nitrite/nitrate reductase activities of XOR, which are realized by the FAD-dependent enzyme site, is not affected when the molybdopterin-containing center of the enzyme is inhibited by allopurinol (Harris and Massey, 1997; Doel et al., 2001; Boueiz et al., 2008). Since there are still no drugs that can inhibit the FAD-dependent activity of XOR, the prescription of heparin, which releases XOP from the connection with glycans and promotes its elimination from the focus of inflammation, is advised in order to prevent pulmonary thromboembolism and to desorb the enzyme from the cytoplasmic membrane of endothelial cells heparin (Povalyaev, 2014; Obi et al., 2019).

Mitochondria are another significant source of reactive oxygen species and metabolites in respiratory viral infections (To et al., 2020). Melatonin as a mitochondrial antioxidant (Reiter et al., 2017) that exhibits anti-inflammatory and immunomodulatory effects, has a pronounced beneficial effect on the course and outcomes of viral infections in the experiment (Srinivasan et al., 2012; Silvestri and Rossi, 2013; Tan et al., 2014; Huang et al., 2019; Zhang et al., 2020).

The superoxide radical anion with respect to organic and inorganic chemical compounds, depending on their chemical nature, can play the role of both an oxidizing agent $\left(\mathrm{E}_{0} \mathrm{O}_{2}^{-\cdot} / \mathrm{H}_{2} \mathrm{O}_{2}=+0.89 \mathrm{~V}\right)$ and a reducing agent $\left(\mathrm{E}_{0} \mathrm{O}_{2} / \mathrm{O}_{2}^{-\cdot}=-0.16 \mathrm{~V}\right)$ (Wood, 1987, 1988). The reducive properties of the superoxide radical produced in pessimal amounts during viral pneumonia in the inflammation zone determine the possibility, in particular, of the reduction of iron ions and their release from complexes with biomacromolecules. For example, in the ferritin composition, iron is presented in the form of $\mathrm{Fe}^{3+}$ ions, which, under the influence of the superoxide radical anion, become $\mathrm{Fe}^{2+}$ and leave the above protein (Biemond et al., 1984; Bolann and Ulvik, 1987). In the presence of free 
iron ions and partially reduced oxygen species, conditions arise for the functioning of a kind of catalytic reactor for the redox catabolic production of prooxidants and, in particular, an extremely toxic hydroxyl radical (Morris et al., 1995). This is also an extremely dangerous state of the biological system, because biological fluids in the presence of free iron ions lose their antibacterial properties (Bullen et al., 1991; Griffiths, 1991; Sritharan, 2006).

The removal of free iron ions from biological media of the organism is a matter of life and death in the course of viral pneumonia. However, attempts to use available chelators (deferoxamine) to bind iron ions in viral pneumonia not only did not have a positive effect on the course of the pathological process, but, contrary to expectations, increased mortality (Dolganova and Sharanov, 1997). The explanation for this paradox is that deferoxamine (desferal), which has an affinity constant for iron ions approximately equal to the siderophores of microorganisms (Hallaway et al., 1989; Askwith et al., 1996), is not able to limit the availability of $\mathrm{Fe}^{3+}$ for pathogenic microorganisms (Kim et al., 2007; Cassat and Skaar, 2013). At the same time, iron ions chelated with deferoxamine apparently do not completely lose the ability to undergo redox transformations and, thus, secure the course of the Fenton and Osipov reactions (Borg and Schaich, 1986; Klebanoff et al., 1989; Dulchavsky et al., 1996; Niihara et al., 2002; Francisco et al., 2010).

In contrast, 2-ethyl-6-methyl-3-hydroxypyridine succinate (mexidol, emoxipine) is characterized by a pronounced iron-chelating effect (Andrusishina et al., 2015), antioxidant activity (Voronina, 2001), and the properties of an inhibitor of serine and matrix proteinases (Zolotov et al., 1989; Akhmedov et al., 2009). With such a list of biological effects, Mexidol can be effectively used as an adjunct in the treatment of pneumonia (Ilyashenko et al., 2003; Luzhnikov et al., 2006) and viral infections (Laseeva, 2009; Pavelkina, 2010).

Chloroquine (in the form of phosphate, hydrochloride or sulfate) has been widely used in clinical practice for more than seven decades, since 1947 (Solomon and Lee, 2009), as a safe, effective and affordable drug:

- for the prevention and treatment of malaria (Mengesha and Makonnen, 1999; Bello et al., 2010; Waqar et al., 2016);

- in the treatment of leprosy (Meinao et al., 1996; Bezerra et al., 2005; Gordon et al., 2018);

- as an anti-inflammatory agent in the treatment of rheumatoid arthritis (Augustijns et al., 1992; Schrezenmeier and Dorner, 2020);

- in a treatment for antiphospholipid syndrome (Tektonidou et al., 2019);

- in the treatment of Sjogren's syndrome (Vivino et al., 2016; Shivakumar et al., 2018; Lee et al., 2019);
- in the treatment of amoebic hepatitis and liver abscesses (Sodeman et al., 1951; Cohen and Reynolds, 1975);

- in the treatment of malignant neoplasms as a means of sensitization (Solomon and Lee, 2009; Maycotte et al., 2012; Kimura et al., 2013);

- in the treatment of metabolic syndrome (Kastan et al., 2007; McGill et al., 2019) and inflammatory diseases of bacterial etiology (as a synergist of antibiotics) (Crowle and May, 1990; Feurle et al., 2012; Son and Chung, 2014).

Chloroquine and its analogs (Delagil, Plaquenil, Immard, Mefloquine, etc.), which exhibit the properties of weakly alkaline amines, easily overcome cell membranes in a nonprotonated form (Chinappi et al., 2010) and, after undergoing protonation, accumulate in closed cell compartments with acidic $\mathrm{pH}$ values (endosomes, lysosomes) (Vincent et al., 2005). The chloroquine level in them can be more than two orders of magnitude higher than its concentration outside the cell (De Duve et al., 1974). Without entering into biotransformation reactions, chloroquine can remain in isolated intracellular compartments for hundreds of hours (Schrezenmeier and Dorner, 2020).

Chloroquine accumulates in endosomes/lysosomes, shifts the $\mathrm{pH}$ value towards the basic values (Homewood et al., 1972; Ohkuma and Poole, 1978; Al-Bari, 2017), and inhibits various ATPases, including $\mathrm{H}^{+}$-ATPase (V-ATPase), which determines the acidification of the of endosomes and cisterns of the Golgi apparatus (Chandra et al., 1992; Bhattacharyya and Sen, 1999; Holliday, 2017). It is possible that the above mentioned phenomena determine the block of release of fragments of the RNA genome of influenza viruses from lipoproteins of their envelope (Shibata et al., 1983), which leads to the suppression of virion replication (Ooi et al., 2006; Di Trani et al., 2007).

The ability of chloroquine to inhibit the acidification of endosomes containing respiratory viruses, and thus block the release of their RNA genomes and subsequent replication are difficult to accept as a satisfactory explanation for its antiviral activity. The fact is that chloroquine exhibits high antiviral activity not only against influenza $\mathrm{A}$ viruses (internalization in endosomes) but also against coronaviruses (Keyaerts et al., 2004; Vincent et al., 2005; Ooi et al., 2006; Yan et al., 2013; De Wilde et al., 2014; Kearney, 2020). Their internalization almost exclusively occurs by means of membrane fusion, i.e., without the stage of endosome formation (Matsuyama et al., 2005).

Among the three types of biological aperiodic polymers (nucleic acids, polypeptides, carbohydrates), aperiodic carbohydrate polymers (glycans, oligosaccharides) are distinguished by the highest information capacity due to their structural features. This provides a high specificity of ligand-receptor interactions of oligosaccharide conjugates. However, the structure of glycans is encoded in the eukaryotic 
genome not directly but indirectly. Oligosaccharides are synthesized in the cisterns of the Golgi apparatus with the participation of secondary protein matrices that form functional heterogeneous associations (conveyor lines) of glycosyltransferases (Chepur et al., 2019). Naturally, the spatial structure of such matrix protein molecules and, consequently, their affinity for enzymes of glycan synthesis can rapidly and significantly change under the influence of the dynamics of the $\mathrm{pH}$ values and the redox potential of the cistern medium of the Golgi apparatus.

Therefore, it is significant that chloroquine is able to change the redox status of the cell (Giovanella et al., 2015) and to decrease the proton concentration (increase the $\mathrm{pH}$ value) in the lumen of the cisterns of the Golgi apparatus by suppressing the activity of ATPases, including $\mathrm{H}^{+}$-ATPase (Reaves and Banting, 1994; Hassinen et al., 2011). It is considered that the most sensitive to the dynamics of $\mathrm{pH}$ value function of the Golgi apparatus is the synthesis of aperiodic oligosaccharides (Kellokumpu, 2019): an increase in $\mathrm{pH}$ by 0.2 units in the lumen of cisterns of the Golgi complex is accompanied by a violation of terminal $\alpha 2,3$-sialylation of both $\mathrm{N}$-linked and $\mathrm{O}$-conjugated glycans (Rivinoja et al., 2006, 2009). Aberrant glycosylation with a decrease in the acidity of the intraluminal medium of the cisterns of the Golgi complex is apparently associated with a $\mathrm{pH}$-induced change in the topology/position of glycosyltransferases in the multienzyme complexes of the synthesis of aperiodic oligosaccharides.

Since all participants in the interaction of human body cells with respiratory RNA viruses (glycoproteins, glycolipids) contain an ample number with glycans with terminal sialic acids, which serve as specific receptors for viral particles, the chloroquine-induced disruption of sialylation/glycosylation processes of cellular and viral participants in this interaction determines the antiviral the effect of drugs in this group.

The involvement of glycans in viral adhesion and replication is extremely important. It should be noted that a number of viruses, including coronaviruses (Milewska et al., 2014, 2018; Szczepanski et al., 2019), use a common heparan sulfate-dependent mechanism of attachment to the cell membrane. Derivatives of dyspirotripiperazine that inhibit the replication of viruses of various families that use heparan sulfate to attach and/or penetrate into the host cell have been obtained (Makarov et al., 2016; Novoselova et al., 2019). The class of compounds involved opens up new possibilities for the inhibition of the process of viral transmission, which has been experimentally proven in a model of infection with the herpes simplex virus of the first type.

A technique used for the prevention/therapy of aspiration and ventilator-associated pneumonia can be adapted for the treatment of virus-associated pneumonia. The main point of the technique is to create a hypoosmotic (up to $200-250 \mathrm{mmol} / \mathrm{L}$ ) medium for autoblood erythrocytes in a solution of a broad spectrum antibiotic with the addition of dimethyl sulfoxide and heparin. The latter is used to improve the rheological properties of blood, to desorb XOR from the luminal surface of endothelial cells, and to remove it from the inflammatory focus. Implementation of the approach makes it possible to avoid hemolysis and, when injected intravenously, to use autoblood erythrocytes as a depot for the targeted delivery of drugs to the inflammatory focus, in particular, to the pneumonia focus where they are released. Dimethyl sulfoxide in generally used amounts $(0.3-0.4 \mathrm{~mL})$ increases the fluidity (reduces microviscosity) and permeability of cell (erythrocyte) membranes and promotes cellular penetration by the antibiotic without any adverse effects on the structure and functional characteristics of the blood corpuscles (Gurtovenko and Anwar, 2007). Moreover, dimethyl sulfoxide inhibits the activation of pro-inflammatory transcription factors NF$\mathrm{kB}, \mathrm{AP}-1$ and the expression of the adhesion molecules ICAM-1 (Chang et al., 2001), blocks the transcription of interleukin genes IL-1, -6 , and -8 an the activation of NLRP3 by inflammas (Ahn et al., 2014; Elisia et al., 2016), and has a pronounced antioxidant activity at extremely low concentrations (Jia et al., 2010; Sanmartin-Suarez et al., 2011).

Up-to-date knowledge of antibiotic properties makes it possible to select drugs with effects that are not associated with bacteriolysis or the release of pathogen-associated molecular patterns (Tauber and Nau, 2008) and those that can implemented without activation of the effector functions of polymorphonuclear leukocytes (Rahman and Mazumder, 2001), their chemotaxis (Burgaleta et al., 1982), or an increase in the activity of neutrophil NADPH oxidase (Umeki, 1995; Dutta et al., 2009).

\section{CONCLUSIONS}

Respiratory RNA viruses are anthropozoonotic infectious pathogens that have natural reservoirs of infection and form a single dynamic gene pool. A single gene pool involves the exchange of genetic material between the genomes of related human and animal RNA viruses. This inevitably leads to the emergence of new, highly virulent strains of pathogens, the time of occurrence and antigenic properties of which cannot be predicted. That is, epidemics of new, respiratory, RNA viral infections will always begin in the absence of drugs for immune prophylaxis and treatment for these infections. The latter predetermines the need for the early search and development of effective means and methods of pathogenetic prevention/therapy for respiratory RNA viral infections.

\section{COMPLIANCE WITH ETHICAL STANDARDS}

Conflict of interests. The authors declare that they have no conflicts of interest. 
Statement on the welfare of humans or animals. This article does not contain any studies involving animals performed by any of the authors.

\section{REFERENCES}

Adachi, T., Fukushima, T., Usami, Y., and Hirano, K., Binding of human xanthine oxidase to sulphated glycosaminoglycans on the endothelial-cell surface, Biochem. J., 1993, vol. 289, no. 2, pp. 523-527.

Agarwal, A., Banerjee, A., and Banerjee, U.C., Xanthine oxidoreductase: a journey from purine metabolism to cardiovascular excitation-contraction coupling, Crit. Rev. Biotechnol., 2011, vol. 31, no. 3, pp. 264-280.

Ahn, H., Kim, J., Jeung, E.B., and Lee, G.S., Dimethyl sulfoxide inhibits NLRP3 activation, Immunobiology, 2014, vol. 219, no. 4, pp. 315-322.

Akaike, T., Ando, M., Oda, T., et al., Dependence on $\mathrm{O}_{2^{-}}$ generation by xanthine oxidase of pathogenesis of influenza virus infection in mice, J. Clin. Invest., 1990, vol. 85 , no. 3 , pp. $739-745$.

Akhmedov, V.A., Budylgin, A.L., Dolgikh, V.E., and Pritykin, T.V., Specific activity of matrix metalloproteinases in chronic recurrent pancreatitis, Vestn. Novosib. Gos. Univ., Ser. Biol., Klin. Med., 2009, vol. 7, no. 4, pp. 117120.

Al-Baadani, A.M., Elzein, F.E., Alhemyadi, S.A., et al., Characteristics and outcome of viral pneumonia caused by influenza and Middle East respiratory syndromecoronavirus infections: a 4-year experience from a tertiary care center, Ann. Thorac. Med., 2019, vol. 14, no. 3, pp. 179-185.

Al-Bari, M.A.A., Targeting endosomal acidification by chloroquine analogs as a promising strategy for the treatment of emerging viral diseases, Pharmacol. Res. Perspect., 2017, vol. 5, no. 1, art. ID e00293.

Al-Muharrmi, Z., Understanding the influenza A H1N1 2009 pandemic, Sultan Qaboos Univ. Med. J., 2010, vol. 10, no. 2, pp. 187-195.

Andrusishina, I.N., Vazhnichaya, E.M., Moklyak, E.V., et al., RF Patent 2557959, 2015.

Askwith, C.C., De Silva, D., and Kaplan, J., Molecular biology of iron acquisition in Saccharomyces cerevisiae, Mol. Microbiol., 1996, vol. 20, no. 1, pp. 27-34.

Augustijns, P., Geusens, P., and Verbeke, N., Chloroquine levels in blood during chronic treatment of patients with rheumatoid arthritis, Eur. J. Clin. Pharmacol., 1992, vol. 42, no. 4, pp. 429-433.

Barbezange, C., Jones, L., Blanc, H., et al., Seasonal genetic drift of human influenza A virus quasispecies revealed by deep sequencing, Front. Microbiol., 2018, vol. 9, art. ID 2596.

Barcena, M., Oostergetel, G.T., Bartelink, W., et al., Cryoelectron tomography of mouse hepatitis virus: insights into the structure of the coronavirion, Proc. Natl. Acad. Sci. U.S.A., 2009, vol. 106, no. 2, pp. 582-587.

Beeh, K.M., Beier, J., Esperester, A., and Paul, L.D., Antiinflammatory properties of ambroxol, Eur. J. Med. Res., 2008, vol. 13, no. 12, pp. 557-562.

Bello, S.O., Chika, A., and Bello, A.Y., Is chloroquine better than artemisinin combination therapy as first line treatment in adult Nigerians with uncomplicated ma- laria? A cost effectiveness analysis, Afr. J. Infect. Dis., 2010, vol. 4, no. 2, pp. 29-42.

Belouzard, S., Chu, V.C., and Whittaker, G.R., Activation of the SARS coronavirus spike protein via sequential proteolytic cleavage at two distinct sites, Proc. Natl. Acad. Sci. U.S.A., 2009, vol. 106, no. 14, pp. 58715876.

Bendikov-Bar, I., Maor, G., Filocamo, M., and Horowitz, M., Ambroxol as a pharmacological chaperone for mutant glucocerebrosidase, Blood Cells Mol. Dis., 2013, vol. 50, no. 2, pp. 141-145.

Bertram, S., Glowacka, I., Blazejewska, P., et al., TMPRSS2 and TMPRSS4 facilitate trypsin-independent spread of influenza virus in Caco-2 cells, J. Virol., 2010, vol. 84, no. 19, pp. 10016-10025.

Bezerra, E.L.M., Vilar, M.J.P., Da Trindade Neto, P.B., and Sato, E.I., Double-blind, randomized, controlled clinical trial of clofazimine compared with chloroquine in patients with systemic lupus erythematosus, Arthritis Rheum., 2005, vol. 52, no. 10, pp. 3073-3078.

Bhattacharyya, D. and Sen, P.C., The effect of binding of chlorpromazine and chloroquine to ion transporting ATPases, Mol. Cell. Biochem., 1999, vol. 198, nos. 1-2, pp. 179-185.

Biemond, P., van Eijk, H.G., Swaak, A.J., and Koster, J.F., Iron mobilization from ferritin by superoxide derived from stimulated polymorphonuclear leukocytes. Possible mechanism in inflammation diseases, J. Clin. Invest., 1984, vol. 73, no. 6, pp. 1576-1579.

Bisno, A.L., Griffin, J.P., van Epps, K.A., et al., Pneumonia and Hong Kong influenza: a prospective study of the 1968-1969 epidemic, Am. J. Med. Sci., 1971, vol. 261, no. 5, pp. 251-263.

Bolann, B.J. and Ulvik, R.J., Release of iron from ferritin by xanthine oxidase. Role of the superoxide radical, Biochem. J., 1987, vol. 243, no. 1, pp. 55-59.

Borg, D.C. and Schaich, K.M., Prooxidant action of desferrioxamine: Fenton-like production of hydroxyl radicals by reduced ferrioxamine, J. Free Radical Biol. Med., 1986, vol. 2, no. 4, pp. 237-243.

Bosch, B.J., van der Zee, R., De Haan, C.A., and Rottier, P.J., The coronavirus spike protein is a class I virus fusion protein: structural and functional characterization of the fusion core complex, J. Virol., 2003, vol. 77, no. 16, pp. 8801-8811.

Boueiz, A., Damarla, M., and Hassoun, P.M., Xanthine oxidoreductase in respiratory and cardiovascular disorder, Am. J. Physiol.: Lung Cell Mol. Physiol., 2008, vol. 294, no. 5, pp. L830-L840.

Boulant, S., Stanifer, M., and Lozach, P.Y., Dynamics of virus-receptor interactions in virus binding, signaling, and endocytosis, Viruses, 2015, vol. 7, no. 6, pp. 27942815.

Bouvier, N.M. and Palese, P., The biology of influenza viruses, Vaccine, 2008, vol. 26, suppl. 4, pp. D49-D53.

Brand, J.D., Lazrak, A., Trombley, J.E., et al., Influenzamediated reduction of lung epithelial ion channel activity leads to dysregulated pulmonary fluid homeostasis, JCI Insight, 2018, vol. 3, no. 20, art. ID 123467.

Brandes, R.P., Koddenberg, G., Gwinner, W., et al., Role of increased production of superoxide anions by $\mathrm{NAD}(\mathrm{P}) \mathrm{H}$ oxidase and xanthine oxidase in prolonged 
endotoxemia, Hypertension, 1999, vol. 33, no. 5, pp. 1243-1249.

Broxmeyer, L., Bird flu, influenza and 1918: the case for mutant avian tuberculosis, Med. Hypotheses, 2006, vol. 67, no. 5, pp. 1006-1015.

Bullen, J.J., Ward, C.G., and Rogers, H.J., The critical role of iron in some clinical infections, Eur. J. Clin. Microbiol. Infect. Dis., 1991, vol. 10, no. 8, pp. 613-617.

Burgaleta, C., Martinez-Beltran, J., and Bouza, E., Comparative effects of moxalactam and gentamicin on human polymorphonuclear leukocyte functions, Antimicrob. Agents Chemother., 1982, vol. 21, no. 5, pp. 718720.

Byrd-Leotis, L., Cummings, R.D., and Steinhauer, D.A., The interplay between the host receptor and influenza virus hemagglutinin and neuraminidase, Int. J. Mol. Sci., 2017, vol. 18, no. 7, art. ID 1541.

Cabral-Romero, C., Martinez-Sanmiguel, J.J., ReséndezPérez, D., et al., Antibacterial and anti-biofilm activities of ambroxol against oral bacteria, Pharma Innovation, 2013, vol. 2, no. 3, pp. 52-58.

Cain, C.C., Sipe, D.M., and Murphy, R.F., Regulation of endocytic $\mathrm{pH}$ by the $\mathrm{Na}^{+}, \mathrm{K}^{+}$-ATPase in living cells, Proc. Natl. Acad. Sci. U.S.A., 1989, vol. 86, no. 2, pp. 544-548.

Callow, K.A., Parry, H.F., Sergeant, M., and Tyrrell, D.A., The time course of the immune response to experimental coronavirus infection of man, Epidemiol. Infect., 1990, vol. 105, no. 2, pp. 435-446.

Cantu-Medellin, N. and Kelley, E.E., Xanthine oxidoreductase-catalyzed reduction of nitrite to nitric oxide: insights regarding where, when and how, Nitric, 2013, vol. 34, pp. 19-26.

Cao, J., Wang, D., Xu, F., et al., Activation of IL-27 signaling promotes development of postinfluenza pneumococcal pneumonia, EMBO Mol. Med., 2014, vol. 6, no. 1 , pp. $120-140$.

Carlson, C.M., Turpin, E.A., Moser, L.A., et al., Transforming growth factor- $\beta$ : activation by neuraminidase and role in highly pathogenic $\mathrm{H} 5 \mathrm{~N} 1$ influenza pathogenesis, PLoS Pathog., 2010, vol. 6, no. 10, art. ID e1001136.

Cassat, J.E. and Skaar, E.P., Iron in infection and immunity, Cell Host Microbe, 2013, vol. 13, no. 5, pp. 509-519.

Cataldi, M., Sblendorio, V., Leo, A., and Piazza, O., Biofilm-dependent airway infections: a role for ambroxol? Pulm. Pharmacol. Ther., 2014, vol. 28, no. 2, pp. 98108.

Chandra, S., Adhikary, G., Sikdar, R., and Sen, P.C., The in vivo inhibition of transport enzyme activities by chloroquine in different organs of rat is reversible, Mol. Cell. Biochem., 1992, vol. 118, no. 1, pp. 15-21.

Chang, C.K., Albarillo, M.V., and Schumer, W., Therapeutic effect of dimethyl sulfoxide on ICAM-1 gene expression and activation of NF- $\kappa \mathrm{B}$ and AP- 1 in septic rats, $J$. Surg. Res., 2001, vol. 95, no. 2, pp. 181-187.

Chardonnet, Y. and Dales, S., Early events in the interaction of adenoviruses with Hela cells. I. Penetration of type 5 and intracellular release of the DNA genome, $\mathrm{Vi}$ rology, 1970, vol. 40, no. 3, pp. 462-477.

Chen, B.H., Park, J.H., Ahn, J.H., et al., Pretreated quercetin protects gerbil hippocampal CA1 pyramidal neu- rons from transient cerebral ischemic injury by increasing the expression of antioxidant enzymes, Neural Regener. Res., 2017, vol. 12, no. 2, pp. 220-227.

Chepur, S.V., Pluzhnikov, N.N., Saiganov, S.A., et al., The hypothesis of the aperiodic polysaccharide matrix synthesis, Usp. Sovrem. Biol., 2019, vol. 139, no. 6, pp. 583-593.

Chepur, S.V., Pluzhnikov, N.N., Saiganov, S.A., et al., Mechanisms of implementation of alpha-tocopherol antioxidant effects, Usp. Sovrem. Biol., 2020, vol. 140, no. 2, pp. 149-165.

Cherry, J.D., The chronology of the 2002-2003 SARS mini pandemic, Paediatr. Respir. Rev., 2004, vol. 5, no. 4, pp. 262-269.

Cheung, P.P., Watson, S.J., Choy, K.T., et al., Generation and characterization of influenza A viruses with altered polymerase fidelity, Nat. Commun., 2014, vol. 5, art. ID 4794.

Chinappi, M., Via, A., Marcatili, P., and Tramontano, A., On the mechanism of chloroquine resistance in Plasmodium falciparum, PLoS One, 2010, vol. 5, no. 11, art. ID e 14064.

Cilloniz, C., Ewig, S., Menendez, R., et al., Bacterial coinfection with $\mathrm{H} 1 \mathrm{~N} 1$ infection in patients admitted with community acquired pneumonia, J. Infect., 2012, vol. 65 , no. 3 , pp. $223-230$.

Cohen, H.G. and Reynolds, T.B., Comparison of metronidazole and chloroquine for the treatment of amoebic liver abscess. A controlled trial, Gastroenterology, 1975, vol. 69 , no. 1 , pp. 35-41.

Crowle, A.J. and May, M.H., Inhibition of tubercle bacilli in cultured human macrophages by chloroquine used alone and in combination with streptomycin, isoniazid, pyrazinamide, and two metabolites of vitamin $\mathrm{D}_{3}, A n-$ timicrob. Agents Chemother., 1990, vol. 34, no. 11, pp. 2217-2222.

Cruveilhier, L., Action du sérum antipneumococcique au cours de la pneumonie et dans les complications de la grippe, Ann. Inst. Pasteur, 1919, vol. 33, pp. 448-461.

Daly, P., Gustafson, R., and Kendall, P., Introduction to pandemic influenza, BC Med. J., 2007, vol. 49, no. 5, pp. $240-244$.

De Duve, C., De Barsy, T., Poole, B., et al., Commentary. Lysosomotropic agents, Biochem. Pharmacol., 1974, vol. 23, no. 18, pp. 2495-2531.

De Haan, C.A. and Rottier, P.J., Molecular interactions in the assembly of coronaviruses, Adv. Virus Res., 2005, vol. 64, pp. 165-230.

De Wilde, A.H., Jochmans, D., Posthuma, C.C., et al., Screening of an FDA-approved compound library identifies four small-molecule inhibitors of Middle East respiratory syndrome coronavirus replication in cell culture, Antimicrob. Agents Chemother., 2014, vol. 58, no. 8, pp. 4875-4884.

Di Trani, L., Savarino, A., Campitelli, L., et al., Different $\mathrm{pH}$ requirements are associated with divergent inhibitory effects of chloroquine on human and avian influenza A viruses, Virol. J., 2007, vol. 4, art. ID 39.

Doel, J.J., Godberg, B.L., Eisenthal, R., and Harrison, R., Reduction of organic nitrates catalyzed by xanthine oxidoreductase under anaerobic conditions, Biochim. 
Biophys. Acta, Gen. Subj., 2001, vol. 1527, nos. 1-2, pp. $81-87$.

Dolganova, A. and Sharonov, B.P., Application of various antioxidants in the treatment of influenza, Braz. J. Med. Biol. Rev., 1997, vol. 30, no. 11, pp. 1333-1336.

Dou, D., Revol, R., Ostbye, H., et al., Influenza A virus cell entry, replication, virion assembly and movement, Front. Immunol., 2018, vol. 9, art. ID 1581.

Drake, J.W., Rates of spontaneous mutation among RNA viruses, Proc. Natl. Acad. Sci. U.S.A., 1993, vol. 90, no. 9, pp. 4171-4175.

Ducatez, M.F., Pelletier, C., and Meyer, G., Influenza D virus in cattle, France, 2011-2014, Emerg. Infect. Dis., 2015, vol. 21, no. 2, pp. 368-371.

Dugan, V.G., Chen, R., Spiro, D.J., et al., The evolutionary genetics and emergence of avian influenza viruses in wild birds, PLoS Pathog., 2008, vol. 4, no. 5, art. ID e1000076.

Dulchavsky, S.A., Davidson, S.B., Cullen, W.J., et al., Effects of deferoxamine on $\mathrm{H}_{2} \mathrm{O}_{2}$-induced oxidative stress in isolated rat heart, Basic Res. Cardiol., 1996, vol. 91, no. 6, pp. 418-424.

Dutta, N.K., Mazumdar, K., and Park, J.H., In vitro synergistic effect of gentamicin with the anti-inflammatory agent diclofenac against Listeria monocytogenes, Lett. Appl. Microbiol., 2009, vol. 48, no. 6, pp. 783-785.

Elisia, I., Nakamura, H., Lam, V., et al., DMSO represses inflammatory cytokine production from human blood cells and reduces autoimmune arthritis, PLoS One, 2016, vol. 11, no. 3, art. ID e0152538.

Ellis, G.T., Davidson, S., Crotta, S., et al., TRAIL ${ }^{+}$monocytes and monocyte-related cells causes lung damage and thereby increase susceptibility to influenza-Streptococcus pneumoniae coinfection, EMBO Rep., 2015, vol. 16, no. 9, pp. 1203-1218.

Fehr, A.R. and Perlman, S., Coronaviruses: an overview of their replication and pathogenesis, Methods Mol. Biol., 2015, vol. 1282, pp. 1-23.

Feurle, G.E., Moos, V., Schneider, T., et al., The combination of chloroquine and micocycline, a therapeutic option in cerebrospinal infection of Whipple's disease refractory to treatment with ceftriaxone, meropenem and co-trimoxazole, J. Antimicrob. Chemother., 2012, vol. 67, no. 5, pp. 1295-1296.

Forni, D., Cagliani, R., Clerici, M., and Sironi, M., Molecular evolution of human coronavirus genomes, Trends Microbiol., 2017, vol. 25, no. 1, pp. 35-48.

Francis, T., A new type of virus from epidemic influenza, Science, 1940, vol. 92, no. 2392, pp. 405-408.

Francisco, A.F., De Abreu Vieira, P.M., Arantes, J.M., et al., Increase of reactive oxygen species by desferrioxamine during experimental Chagas' disease, Redox Rep., 2010, vol. 15, no. 4, pp. 185-190.

Frederiks, W.M. and Vreeling-Sindelárová, H., Ultrastructural localization of xanthine oxidoreductase activity in isolated rat liver cells, Acta Histochem., 2002, vol. 104, no. 1, pp. 29-37.

Garten, R.J., Davis, C.T., Russell, C.A., et al., Antigenic and genetic characteristics of swine-origin $\mathrm{A}(\mathrm{H} 1 \mathrm{~N} 1)$ influenza viruses circulating in humans, Science, 2009, vol. 325, no. 5937, pp. 197-201.
Garten, W., Braden, C., Arendt, A., et al., Influenza virus activating host proteases: identification, localization and inhibitors as potential therapeutics, Eur. J. Cell Biol., 2015, vol. 94, nos. 7-9, pp. 375-383.

Gaunt, E.R., Hardie, A., Claas, E.C.J., et al., Epidemiology and clinical presentation of the four human coronaviruses 229E, HKU1, NL63, and OC43 detected over 3 years using a novel multiplex real-time PCR method, J. Clin. Microbiol., 2010, vol. 48, no. 8, pp. 2940-2947.

George, J. and Struthers, A.D., Role of urate, xanthine oxidase and the effects of allopurinol in vascular oxidative stress, Vasc. Health Risk Manage., 2009, vol. 5, no. 1, pp. 265-272.

Gholampour, F. and Saki, N., Hepatic and renal protective effects of quercetin in ferrous sulfateinduced toxicity, Gen. Physiol. Biophys., 2019, vol. 38, no. 1, pp. 27-38.

Ghoneim, H.E., Thomas, P.G., and McCullers, J.A., Depletion of alveolar macrophages during influenza infection facilitates bacterial superinfection, J. Immunol., 2013, vol. 191, no. 3, pp. 1250-1259.

Gibbs, B.F., Schmutzler, W., Vollrath, I.B., et al., Ambroxol inhibits the release of histamine, leukotrienes and cytokines from human leukocytes and mast cells, Inflamm. Res., 1999, vol. 48, no. 2, pp. 86-93.

Gill, J.R., Sheng, Z.M., Ely, S.F., et al., Pulmonary pathologic findings of fatal 2009 pandemic influenza A/H1N1 viral infections, Arch. Pathol. Lab. Med., 2010, vol. 134, no. 2, pp. 235-243.

Giovanella, F., Ferreira, G.K., De Pra, S.D., et al., Effects of primaquine and chloroquine on oxidative stress parameters in rats, An. Acad. Bras. Ciênc., 2015, vol. 87, no. 2, pp. 1487-1496.

Gordon, C., Amissah-Arthur, M.B., Gayed, M., et al., The British Society for Rheumatology guideline for the management of systemic lupus erythematosus in adults: executive summary, Rheumatology, 2018, vol. 57, no. 1, pp. e1-e45.

Griffiths, E., Iron and bacterial virulence-a brief overview, Biol. Met., 1991, vol. 4, no. 1, pp. 7-13.

Gupta, P.R., Ambroxol-resurgence of an old molecule as an anti-inflammatory agent in chronic obstructive airway diseases, Lung India, 2010, vol. 27, no. 2, pp. 4648.

Gurtovenko, A.A. and Anwar, J., Modulating the structure and properties of cell membranes: the molecular mechanism of action of dimethyl sulfoxide, J. Phys. Chem. B, 2007, vol. 111, no. 35, pp. 10453-10460.

Haijema, B.J., Volders, H., and Rottier, P.J., Switching species tropism: an effective way to manipulate the feline coronavirus genome, J. Virol., 2003, vol. 77, no. 8, pp. 4528-4538.

Hallaway, P.E., Eaton, J.W., Panter, S.S., and Hedlund, B.E., Modulation of deferoxamine toxicity and clearance by covalent attachment to biocompatible polymers, Proc. Natl. Acad. Sci. U.S.A., 1989, vol. 86, no. 24, pp. 10108-10112.

Hamre, D. and Procknow, J.J., A new virus isolated from the human respiratory tract, Proc. Soc. Exp. Biol. Med., 1966, vol. 121, no. 1, pp. 190-193.

Hanada, S., Pirzadeh, M., Carver, K.Y., and Deng, J.C., Respiratory viral infection-induced microbiome alter- 
ations and secondary bacterial pneumonia, Front. Immunol., 2018, vol. 9, art. ID 2640.

Harris, C.M. and Massey, V., The reaction of reduced xanthine dehydrogenase with molecular oxygen. Reaction kinetics and measurement of superoxide radical, J. Biol. Chem., 1997, vol. 272, no. 13, pp. 8370-8379.

Hassinen, A., Pujol, F.M., Kokkonen, N., et al., Functional organization of Golgi N- and O-glycosylation pathways involves $\mathrm{pH}$-dependent complex formation that is impaired in cancer cells, J. Biol. Chem., 2011, vol. 286, no. 44 , pp. 38329-38340.

Hause, B.M., Ducatez, M., Collin, E.A., et al., Isolation of a novel swine influenza virus from Oklahoma in 2011 which is distantly related to human influenza $\mathrm{C}$ virus, PLoS Pathog., 2013, vol. 9, no. 2, art. ID e1003176.

Henkel, M., Mitzner, D., Henklein, P., et al., The proapoptotic influenza A virus protein PB1-F2 forms a nonselective ion channels, PLoS One, 2010, vol. 5, no. 6 , art. ID e 11112 .

Heurich, A., Hofmann-Winkler, H., Gierer, S., et al., TMPRSS2 and ADAM17 cleave ACE2 differentially and only proteolysis by TMPRSS2 augments entry driven by the severe acute respiratory syndrome coronavirus spike protein, J. Virol., 2014, vol. 88, no. 2, pp. 1293-1307.

Holliday, L.S., Vacuolar $\mathrm{H}^{+}$-ATPases (V-ATPases) as therapeutic targets: a brief review and recent developments, Biotarget, 2017, vol. 1, art. ID 18.

Holmes, K.V., Coronaviruses, in Fields Virology, Knipe, D.M. and Howley, P.M., Eds., Philadelphia: Lippincott Williams and Wilkins, 2001, pp. 1187-1203.

Holmes, E.C., Ghedin, E., Miller, N., et al., Whole-genome analysis of human influenza A virus reveals multiple persistent lineages and reassortment among recent H3N2 viruses, PLoS Biol., 2005, vol. 3, no. 9, art. ID e300.

Homewood, C.A., Warhurst, D.C., Peters, W., and Baggaley, V.C., Lysosomes, $\mathrm{pH}$ and the anti-malarial action of chloroquine, Nature, 1972, vol. 235, no. 5332, pp. 50-52.

Huang, C., Liu, W.J., Xu, W., et al., A bat-derived putative cross-family recombinant coronavirus with a reovirus gene, PLoS Pathog., 2016, vol. 12, no. 9, art. ID e1005883.

Huang, S.H., Liao, C.L., Chen, S.J., et al., Melatonin possesses an anti-influenza potential through its immune modulatory effect, J. Funct. Foods, 2019, vol. 58, pp. 189-198.

Hui, D.S., Azhar, E.I., Madani, T.A., and Ntoumi, F., The continuing 2019-nCoV epidemic threat of a novel coronaviruses to global health-the latest 2019 novel coronavirus outbreak in Wuhan, China, Int. J. Infect. Dis., 2020, vol. 91, pp. 264-266.

Hulswit, R.J., Lang, Y., Bakkers, M.J., et al., Human coronaviruses OC43 and HKU1 bind to 9-O-acetylated sialic acid via a conserved receptor-binding site in spike protein domain A, Proc. Natl. Acad. Sci. U.S.A., 2019, vol. 116, no. 7, pp. 2861-2890.

Hutchinson, C.E., Charles, P.D., Hester, S.S., et al., Conserved and host-specific features of influenza virion architecture, Nat. Commun., 2014, vol. 5, art. ID 4816.
Ibricevic, A., Pekosz, A., Walter, M.J., et al., Influenza virus receptor specificity and cell tropism in mouse and human airway epithelial cells, J. Virol., 2006, vol. 80, no. 15 , pp. $7469-7480$.

Il'yashenko, K.K., Luzhnikov, E.A., Abakumov, M.M., et al., RF Patent 2205641, 2003.

Ishiguro, T., Kagiyama, N., Uozumi, R., et al., Clinical characteristics of influenza-associated pneumonia of adults: clinical features and factors contributing to severity and mortality, Yale J. Biol. Med., 2017, vol. 90, no. 2 , pp. $165-181$.

Jansson, E.A., Huang, L., Malkey, R., et al., A mammalian functional reductase that regulates nitrite and nitric oxide homeostasis, Nat. Chem. Biol., 2008, vol. 4, no. 7, pp. 411-417.

Jauch, R., Bozler, G., Hammer, R., et al., Ambroxol, studies of biotransformation in man and determination in biological samples, Arzneimittelforschung, 1978, vol. 28, no. 5, pp. 904-911.

Jia, Z., Zhu, H., Li, Y., and Misra, H.P., Potent inhibition of peroxynitrite-induced DNA strand breakage and hydroxyl radical formation by dimethyl sulfoxide at very low concentration, Exp. Biol. Med., 2010, vol. 235, no. 5, pp. 614-622.

Jo, S., Kim, H., Kim, S., et al., Characteristics of flavonoids as potent MERS-CoV 3C-like protease inhibitors, Chem. Biol. Drug Des., 2019, vol. 94, no. 6, pp. 2023-2030.

Johnson, N.P. and Mueller, J., Updating the accounts: global mortality of the 1918-1920 "Spanish" influenza pandemic, Bull. Hist. Med., 2002, vol. 76, no. 1, pp. 105-115.

Kamal, R.P., Alymova, I.V., and York, I.A., Evolution and virulence of influenza A virus protein PB1 F2, Int. J. Mol. Sci., 2017, vol. 19, no. 1, art. ID 96.

Kartenbeck, J., Stukenbrok, H., and Helenius, A., Endocytosis of simian virus 40 into the endoplasmic reticulum, J. Cell Biol., 1989, vol. 109, no. 6, pp. 2721-2729.

Kastan, M.B., Semenkovich, C.F., and Schneider, J., US Patent 8440695B2, 2013.

Kearney, J., Chloroquine as a potential treatment and prevention measure for the 2019 novel coronavirus: a review, Preprints, 2020, art. ID 202003.0275.

Keck, J.G., Matsushima, G.K., Makino, S., et al., In vivo RNA-RNA recombination of coronavirus in mouse brain, J. Virol., 1988, vol. 62, no. 5, pp. 1810-1813.

Kellokumpu, S., Golgi pH, ion and redox homeostasis: how much do they really matter? Front. Cell Dev. Biol., 2019, vol. 7, art. ID 93.

Kern, K.U. and Weiser, T., Topisches Ambroxol zur Behandlung neuropathischer Schmerzen, Der Schmerz, 2015, vol. 29, no. 6, pp. 632-640.

Keyaerts, E., Vijgen, L., Maes, P., et al., In vitro inhibition of severe acute respiratory syndrome coronavirus by chloroquine, Biochem. Biophys. Res. Commun., 2004, vol. 323, no. 1, pp. 264-268.

Khomich, O.A., Kochetkov, S.N., Bartosch, B., and Ivanov, A.V., Redox biology of respiratory viral infections, Viruses, 2018, vol. 10, no. 8, art. ID e392.

Kido, H., Okumura, Y., Yamada, H., et al., Secretory leukoprotease inhibitor and pulmonary surfactant serve as 
principal defenses against influenza A virus infection in the airway and chemical agents up-regulating their levels may have therapeutic potential, Biol. Chem., 2004, vol. 385, no. 11, pp. 1029-1034.

Kido, H., Okumura, Y., Takahashi, E., et al., Host envelope glycoprotein processing proteases are indispensable for entry into human cells by seasonal and highly pathogenic avian influenza viruses, J. Mol. Genet. Med., 2009, vol. 3, no. 1, pp. 167-175.

Kilbourne, E.D., Influenza pandemics of the 20th century, Emerg. Infect. Dis., 2006, vol. 12, no. 1, pp. 9-14.

Kim, C.M., Park, Y.J., and Shin, S.H., A widespread deferoxamine-mediated iron-uptake system in Vibrio vulnificus, J. Infect. Dis., 2007, vol. 196, no. 10, pp. 1537-1545.

Kim, P., Jang, Y.H., Kwon, S.B., et al., Glycosylation of hemagglutinin and neuraminidase of influenza A virus as signature for ecological spillover and adaptation among influenza reservoirs, Viruses, 2018, vol. 10, no. 4, art. ID 183 .

Kimura, T., Takabatake, Y., Takahashi, A., and Isaka, Y., Chloroquine in cancer therapy: a double-edged sword of autophagy, Cancer Res., 2013, vol. 73, no. 1, pp. 3-7.

King, A.M.Q., Lefkowitz, E.L., Mushegian, A.R., et al., Changes to taxonomy and the international code of virus classification and nomenclature ratified by the International Committee on Taxonomy of Viruses, Arch. Virol., 2018, vol. 163, no. 9, pp. 2601-2631.

Klebanoff, S.J., Waltersdorph, A.M., Michel, B.R., and Rosen, H., Oxygen-based free radicals generation by ferrous ions and deferoxamine, J. Biol. Chem., 1989, vol. 264, no. 33, pp. 19765-19771.

Klenk, H.D., Rott, R., Orlich, M., and Blödorn, J., Activation of influenza A viruses by trypsin treatment, Virology, 1975, vol. 68, no. 2, pp. 426-439.

Koetz, A., Nilsson, P., Linden, M., et al., Detection of human coronavirus NL63, human metapneumovirus and respiratory syncytial virus in children with respiratory tract infections in south-west Sweden, Clin. Microbiol. Infect., 2006, vol. 12, no. 11, pp. 1089-1096.

Kosik, I. and Yewdell, J.W., Influenza hemagglutinin and neuraminidase: Yin-Yang proteins coevolving to thwart immunity, Viruses, 2019, vol. 11, no. 4, art. ID 346.

Kumlin, U., Olofsson, S., Dimock, K., and Arnberg, N., Sialic acid tissue distribution and influenza virus tropism, Influenza Other Respir. Viruses, 2008, vol. 2, no. 5, pp. 147-154.

Kuszewski, K. and Brydak, L., The epidemiology and history of influenza, Biomed. Pharmacother., 2000, vol. 54, no. 4, pp. $188-195$.

Lai, M.M., Coronavirus: organization, replication and expression of genome, Ann. Rev. Microbiol., 1990, vol. 44, pp. 303-333.

Lai, M.M. and Cavanagh, D., The molecular biology of coronaviruses, Adv. Virus Red., 1997, vol. 28, pp. 35112.

Laseeva, M.G., Clinical and pathogenetic features of endogenous intoxication syndrome and its possible correction in some viral infections, Cand. Sci. (Med.) Dissertation, Saransk: Ogarev Mordova State Univ., 2009.

Lazarowitz, S.G. and Choppin, P.W., Enhancement of the infectivity of influenza A and B viruses by proteolytic cleavage of the hemagglutinin polypeptide, Virology, 1975, vol. 68, no. 2, pp. 440-454.

Lee, H.J., Shin, S., Yoon, S.G., et al., The effect of chloroquine on the development of dry eye in Sjogren syndrome animal model, Invest. Ophthalmol. Visual Sci., 2019, vol. 60, no. 12, pp. 3708-3716.

Leung, H.S., Li, O.T., Chan, R.W., et al., Entry of influenza A virus with a $\alpha 2,6$-linked sialic acid binding preference requires host fibronectin, J. Virol., 2012, vol. 86, no. 19, pp. 10704-10713.

Li, F., Evidence for a common evolutionary origin of coronavirus spike protein receptor-binding subunits, J. Virol., 2012, vol. 86, no. 5, pp. 2856-2858.

Li, F., Structure, function, and evolution of coronavirus spike proteins, Ann. Rev. Virol., 2016, vol. 3, no. 1, pp. 237-261.

Li, F., Wang, W., Hu, L., et al., Effect of ambroxol on pneumonia caused by Pseudomonas aeruginosa with biofilm formation in an endotracheal intubation rat model, Chemotherapy, 2011, vol. 57, no. 2, pp. 173-180.

Li, W., Hulswit, R.J., Widjaja, I., et al., Identification of sialic acid-binding function for the Middle East respiratory syndrome coronavirus spike glycoprotein, Proc. Natl. Acad. Sci. U.S.A., 2017, vol. 114, no. 40, pp. E8508-E8517.

Lim Y.X., Ng Y.L., Tam J.P., and Liu, D.X., Human coronaviruses: a review of virus-host interactions, Diseases, 2016, vol. 4, no. 3, art. ID 26.

Limburg, H., Harbig, A., Bestle, D., et al., TMPRSS2 is the major activating protease of influenza A virus in primary human airway cells and influenza B virus in human type II pneumocytes, J. Virol., 2019, vol. 93, no. 21, art. ID e00649-19.

Lin, C.W., Lin, K.H., Hsieh, T.H., et al., Severe acute respiratory syndrome coronavirus 3C-like protease-induced apoptosis, FEMS Immunol. Med. Microbiol., 2006, vol. 46, no. 3, pp. 375-380.

Linder, N., Martelin, E., Lapatto, R., and Raivio, K.O., Posttranslational inactivation of human xanthine oxidoreductase by oxygen under standard cell culture conditions, Am. J. Physiol.: Cell Physiol., 2003, vol. 285, no. 1, pp. C48-C55.

Liu, M., Chen, F., Liu, T., et al., The role of oxidative stress in influenza virus infection, Microbes Infect., 2017, vol. 19, no. 12, pp. 580-586.

Lu, Q., Yu, J., Yang, X., et al., Ambroxol interferes with Pseudomonas aeruginosa quorum sensing, Int. J. Antimicrob. Agents, 2010, vol. 36, no. 3, pp. 211-215.

Luzhnikov, E.A., Il'yashenko, K.K., Pinchuk, T.P., and Ermokhina, T.V., Application of Mexidol for the complex therapy of patients with acute exogenous poisoning, Byull. Eksp. Biol. Med., 2006, suppl. 1, pp. 190198.

Makarov, V.A., Monakhova, N.S., and Ryabova, O.B., RF Patent 2573977, 2016.

Makino, S., Keck, J.G., Stohlman, S.A., and Lai, M.M., High-frequency RNA recombination of murine coronaviruses, J. Virol., 1986, vol. 57, no. 3, pp. 729-737.

Manzoor, R., Igarashi, M., and Takada, A., Influenza A virus M2 protein: roles from ingress to egress, Int. J. Mol. Sci., 2017, vol. 18, no. 12, art. ID 2649. 
Martin-Loeches, I., Sanchez-Carral, A., Diaz, E., et al., Community-acquired respiratory co-infection in critically ill patients with pandemic 2009 influenza $\mathrm{A}(\mathrm{H} 1 \mathrm{N1})$ virus, Chest, 2011, vol. 139, no. 3, pp. 555562.

Maruyama, T., Fujisawa, T., Suga, S., et al., Outcomes and prognostic features of patients with influenza requiring hospitalization and receiving early antiviral therapy: a prospective multicenter cohort study, Chest, 2016, vol. 149 , no. 2 , pp. 526-534.

Matlin, K.S., Reggio, H., Helenius, A., and Simons, K., Infectious entry pathway of influenza virus in a canine kidney cell line, J. Cell. Biol., 1981, vol. 91, no. 3, pp. 601-613.

Matsuyama, S., Ujike, M., Morikawa, S., et al., Proteasemediated enhancement of severe acute respiratory syndrome coronavirus infection, Proc. Natl. Acad. Sci. U.S.A., 2005, vol. 102, no. 35, pp. 12543-12547.

Maycotte, P., Aryal, S., Cummings, C.T., et al., Chloroquine sensitizes breast cancer cells to chemotherapy independent of autophagy, Autophagy, 2012, vol. 8, no. 2, pp. 200-212.

McAuley, J.L., Hornung, F., Boyd, K.L., et al., Expression of the 1918 influenza A virus PB1-F2 enhances the pathogenesis of viral and secondary bacterial pneumonia, Cell Host Microbe, 2007, vol. 2, no. 4, pp. 240-248.

McBride, R., van Zyl, M., and Fielding, B.C., The coronavirus nucleocapsid is a multifunctional protein, Viruses, 2014, vol. 6, no. 8, pp. 2991-3018.

McGill, J.B., Johnson, M., Hurst, S., et al., Low dose chloroquine decreases insulin resistance in human metabolic syndrome but does not reduce carotid intima-media thickness, Diabetol. Metab. Syndr., 2019, vol. 11, art. ID 61 .

McIntosh, K., Kapikian, A.Z., Turner, H.C., et al., Seroepidemiological studies of coronavirus infection in adults and children, Am. J. Epidemiol., 1970, vol. 91, no. 6 , pp. 585-592.

McNamee, L.A. and Harmsen, A.G., Both influenza-induced neutrophil dysfunction and neutrophil-independent mechanisms contribute to increased susceptibility to a secondary Streptococcus pneumoniae infection, Infect. Immun., 2006, vol. 74, no. 12, pp. 6707-6721.

Meinao, I.M., Sato, E.I., Andrade, L.E., et al., Controlled trial with chloroquine diphosphate in systemic lupus erythematosus, Lupus, 1996, vol. 5, no. 3, pp. 237-241.

Mengesha, T. and Makonnen, E., Comparative efficacy and safety of chloroquine and alternative antimalarial drugs: a meta-analysis from six African countries, East Afr. Med. J., 1999, vol. 76, no. 6, pp. 314-319.

Metersky, M.L., Masterton, R.G., Lode, H., et al., Epidemiology, microbiology, and treatment considerations for bacterial pneumonia complicating influenza, Int. J. Infect. Dis., 2012, vol. 16, no. 5, pp. e321-e331.

Milewska, A., Zarebski, M., Nowak, P., et al., Human coronavirus NL63 utilizes heparan sulfate proteoglycans for attachment to target cells, J. Virol., 2014, vol. 88 , no. 22 , pp. $13221-13230$.

Milewska, A., Nowak, P., Owczarek, K., et al., Entry of human coronavirus NL63 into the cell, J. Virol., 2018, vol. 92, no. 3, art. ID e01933-17.
Mitnaul, L.J., Matrosovich, M.N., Castrucci, M.R., et al., Balanced hemagglutinin and neuraminidase activities are critical for efficient replication of influenza A virus, J. Virol., 2000, vol. 74, no. 13, pp. 6015-6020.

Morens, D.M., Taubenberger, J.K., and Fauci, A.S., Predominant role of bacterial pneumonia as a cause of death in pandemic influenza: implications for pandemic influenza preparedness, J. Infect. Dis., 2008, vol. 198, no. 7, pp. 962-970.

Morris, C.J., Earl, J.R., Trenam, C.W., and Blake, D.R., Reactive oxygen species and iron-a dangerous partnership in inflammation, Int. J. Biochem. Cell Biol., 1995, vol. 27, no. 2, pp. 109-122.

Muramoto, Y., Noda, T., Kawakami, E., et al., Identification of novel influenza A virus proteins translated from PA mRNA, J. Virol., 2013, vol. 87, no. 5, pp. 24552462.

Nakagawa, K., Lokugamage, K.G., and Makino, S., Viral and cellular mRNA translation in coronavirus-infected cells, Adv. Virus Res., 2016, vol. 96, pp. 165-192.

Nal, B., Chan, C., Kien, F., et al., Differential maturation and subcellular localization of severe acute respiratory syndrome coronavirus surface proteins $\mathrm{S}, \mathrm{M}$ and E, $J$. Gen. Virol., 2005, vol. 86, no. 5, pp. 1423-1434.

Nanbo, A., Imai, M., Watanabe, S., et al., Ebolavirus is internalized into host cells via macropinocytosis in a viral glycoprotein-dependent manner, PLoS Pathog., 2010, vol. 6, no. 9, art. ID e1001121.

Neuman, B.W., Adair, B.D., Yoshioka, C., et al., Supramolecular architecture of severe acute respiratory syndrome coronavirus revealed by electron cryomicroscopy, J. Virol., 2006, vol. 80, no. 16, pp. 7918-7928.

Neuman, B.W., Kiss, G., Kunding, A.H., et al., A structural analysis of $\mathbf{M}$ protein in coronavirus assembly and morphology, J. Struct. Biol., 2011, vol. 174, no. 1, pp. 11-22.

Niihara, Y., Ge, J., Shalev, O., et al., Desferrioxamine decreases NAD redox potential of intact red blood cells: evidence for desferrioxamine as an inducer of oxidant stress in red blood cells, BMC Clin. Pharmacol., 2002, vol. 2, no. 1, art. ID 8.

Nita-Lazar, M., Banerjee, A., Feng, C., et al., Desialylation of airway epithelial cells during influenza virus infection enhances pneumococcal adhesion via galectins binding, Mol. Immunol., 2015, vol. 65, no. 1, pp. 1-16.

Novoselova, E.A., Ryabova, O.B., Leneva, I.A., and Makarov, V.A., Specific antiviral activity of pyrimidinedyspirotripiperazinium in monotherapy and in combination with acyclovir in a model of herpesvirus infection, Khim.-Parm. Zh., 2019, vol. 53, no. 9, pp. 3-8.

Nowak, D., Antczak, A., Krol, M., et al., Antioxidant properties of ambroxol, Free Radical Biol. Med., 1994, vol. 16, no. 4, pp. 517-552.

Obi, A.T., Tignanelli, C.J., Jacobs, B.N., et al., Empirical systemic anticoagulation is associated with decreased venous thromboembolism in critically ill influenza A H1N1 acute respiratory distress syndrome patients, $J$. Vasc. Surg.: Venous Lymphatic Disord., 2019, vol. 7, no. 3 , pp. 317-324.

Ohkuma, S. and Poole, B., Fluorescence probe measurement of the intralysosomal $\mathrm{pH}$ in living cells and the 
perturbation of $\mathrm{pH}$ by various agents, Proc. Natl. Acad. Sci. U.S.A., 1978, vol. 75, no. 7, pp. 3327-3331.

Olitsky, P.K. and Gates, F.L., Experimental studies of the nasopharyngeal secretions from influenza patients. I. Transmission experiments with nasopharyngeal washings, J. Exp. Med., 1921a, vol. 33, no. 2, pp. 125-145.

Olitsky, P.K. and Gates, F.L., Experimental studies of the nasopharyngeal secretions from influenza patients. II. Filterability and resistance to glycerol, J. Exp. Med., 1921b, vol. 33, no. 3, pp. 361-372.

Ooi, E.E., Chew, J.S., Loh, J.P., and Chua, R.C., In vitro inhibition of human influenza A virus replication by chloroquine, Virol. J., 2006, vol. 3, art. ID 39.

Oswald, N.C., Shooter, R.A., and Curwen, M.P., Pneumonia complicating Asian influenza, Br. Med. J., 1958, vol. 2, no. 5108, pp. 1305-1311.

Ozgen, S., Kilinc, O.K., and Selamoglu, Z., Antioxidant activity of quercetin: a mechanistic review, Turk. J. Agric., Food Sci. Technol., 2016, vol. 4, no. 12, pp. 11341138.

Pacher, P., Novorozhkin, A., and Szabo, C., Therapeutic effects of xanthine oxidase inhibitors: renaissance half a century after the discovery of allopurinol, Pharmacol. Rev., 2006, vol. 58, no. 1, pp. 87-114.

Page, S., Powell, D., Benboubetra, M., et al., Xanthine oxidoreductase in human mammary epithelial cells: activation in response to inflammatory cytokines, Biochim. Biophys. Acta, Gen. Subj., 1998, vol. 1381, no. 2, pp. 191-202.

Palacios, G., Hornig, M., Cisterna, D., et al., Streptococcus pneumoniae coinfection is correlated with the severity of HINI pandemic influenza, PLoS One, 2009, vol. 4 , no. 12 , art. ID e8540.

Pappas, G., Kiriaze, I.J., and Falagas, M.E., Insights into infectious disease in the era of Hippocrates, Int. J. Infect. Dis., 2008, vol. 12, no. 4, pp. 347-350.

Parsons, L., Bouwman, K.M., Azurmendi, H., et al., Glycosylation of the viral attachment protein of avian coronavirus is essential for host cell and receptor binding, $J$. Biol. Chem., 2019, vol. 294, no. 19, pp. 7797-7809.

Pavelkina, V.F., Clinical and pathogenetic aspects of endogenous intoxication and its correction in diseases of viral and bacterial etiology, Doctoral (Med.) Dissertation, Moscow: Sechenov Med. Univ., 2010.

Pensaert, M.B., Porcine epidemic diarrhea, in Diseases of Swine, Straw, B.E., D'Allaire, S., Mengeling, W.L., and Taylor, D., Eds., Ames: Iowa State Univ. Press, 1999, pp. 179-185.

Peteranderl, C., Morales-Nebreda, L., Selvakumar, B., et al., Macrophage-epithelial paracrine crosstalk inhibits lung edema clearance during influenza infection, $J$. Clin. Invest., 2016, vol. 126, no. 4, pp. 1566-1580.

Pfeiffer, R.F.J., Die Aetiologie der Influenza, Z. Hyg. Infektionskrankh., 1893, vol. 13, pp. 357-386.

Pinto, L.H., Holsinger, L.J., and Lamb, R.A., Influenza virus M2 protein has ion channel activity, Cell, 1992, vol. 69 , no. 3 , pp. $517-528$.

Pittet, L.A., Hall-Stoodley, L., Rutkowski, M.R., and Harmsen, A.G., Influenza virus infection decreases tracheal mucociliary velocity and clearance of Streptococcus pneumonia, Am. J. Respir. Cell Mol. Biol., 2010, vol. 42, no. 4, pp. 450-460.
Poss, W.B., Huecksteadt, T.R., Panus, P.C., et al., Regulation of xanthine dehydrogenase and xanthine oxidase activity by hypoxia, Am. J. Physiol., 1996, vol. 270, no. 6, pp. L941-L946.

Potter, C.W., A history of influenza, J. Appl. Microbiol., 2001, vol. 91 , no. 4 , pp. 572-579.

Povalyaev, D., The efficacy of adjuvant use low molecular weight heparins in patients with community-acquired pneumonia, Eur. Respir. J., 2014, vol. 44, suppl. 58, art. ID P2503.

Quan, F.S., Lee, Y.T., Kim, K.H., et al., Progress in developing virus-like particle influenza vaccines, Exp. Rev. Vacc., 2016, vol. 15, no. 10, pp. 1281-1293.

Rahman, M.U. and Mazumder, A., The immunomodulatory effects of gentamicin, imipenem, piperacillin and amphotericin B on LAK effector function in vitro, FEMS Immunol. Med. Microbiol., 2001, vol. 30, no. 3, pp. 249-252.

Ramadan, N. and Shaib, H., Middle East respiratory syndrome coronavirus (MERS-CoV): a review, Germs, 2019, vol. 9, no. 1, pp. 35-42.

Reaves, B. and Banting, G., Vacuolar ATPase inactivation blocks recycling to the trans-Golgi network from the plasma membrane, FEBS Lett., 1994, vol. 345, no. 1, pp. $61-66$.

Reiter, R.J., Rosales-Corral, S., Tan, D.X., et al., Melatonin as a mitochondria-targeted antioxidant: one of evolution's best ideas, Cell Mol. Life Sci., 2017, vol. 74, no. 21 , pp. $3863-3881$.

Rejmanek, D., Hosseini, P.R., Mazet, J.A., et al., Evolutionary dynamics and global diversity of influenza A virus, J. Virol., 2015, vol. 89, no. 21, pp. 10993-11001.

Ren, L., Zhang, Y., Li, J., et al., Genetic drift of human coronavirus OC43 spike gene during adaptive evolution, Sci. Rep., 2015, vol. 5, art. ID 11451.

Rivinoja, A., Kokkonen, N., Kellokumpu, I., and Kellokumpu, S., Elevated Golgi pH in breast and colorectal cancer cells correlates with the expression of oncofetal carbohydrate T-antigen, J. Cell. Physiol., 2006, vol. 208, no. 1, pp. 167-174.

Rivinoja, A., Hassinen, A., Kokkonen, N., et al., Elevated Golgi $\mathrm{pH}$ impairs terminal N-glycosylation by inducing mislocalization of Golgi glycosyltransferases, J. Cell Physiol., 2009, vol. 220, no. 1, pp. 144-154.

Rogers, D.F., Mucoactive agents for airway mucus hypersecretory diseases, Respir. Care, 2007, vol. 52, no. 9, pp. 1176-1193.

Rojek, J.M., Perez, M., and Kunz, S., Cellular entry of lymphocytic choriomeningitis virus, J. Virol., 2008, vol. 82 , no. 3, pp. 1505-1517.

Rouquette, M., Page, S., Bryant, R., et al., Xanthine oxidoreductase is asymmetrically localized on the outer surface of human endothelial and epithelial cells in culture, FEBS Lett., 1988, vol. 426, no. 3, pp. 397-401.

Samji, T., Influenza A: understanding the viral life cycle, Yale J. Biol. Med., 2009, vol. 82, no. 4, pp. 153-159.

Sanchez-Martinez, A., Beavan, M., Gegg, M.E., and Chau, K., Parkinson disease-linked GBA mutation effects reversed by molecular chaperones in human cell and fly models, Sci. Rep., 2016, vol. 6, art. ID 31380. 
Sanmartín-Suárez, C., Soto-Otero, R., Sánchez-Sellero, I., and Méndez-Álvarez, E., Antioxidant properties of dimethyl sulfoxide and its viability as a solvent in the evaluation of neuroprotective antioxidants, J. Pharmacol. Toxicol. Methods, 2011, vol. 63, no. 2, pp. 209-215.

Schoeman, D. and Fielding, B.C., Coronavirus envelope protein: current knowledge, Virol. J., 2019, vol. 16, no. 1, art. ID 69.

Scholtissek, C., Rohde, W., von Hoyningen, V., and Rott R., On the origin of the human influenza virus subtypes H2N2 and H3N2, Virology, 1978, vol. 87, no. 1, pp. 13-20.

Schrezenmeier, E. and Dorner, T., Mechanisms of action of hydroxychloroquine and chloroquine: implications for rheumatology, Nat. Rev. Rheumatol., 2020, vol. 16, no. 3, pp. $155-166$.

Schwarz, K.B., Oxidative stress during viral infection: a review, Free Radical Biol. Med., 1996, vol. 21, no. 5, pp. 641-649.

Seifart, C., Clostermann, U., Seifart, U., et al., Cell-specific modulation of surfactant proteins by ambroxol treatment, Toxicol. Appl. Pharmacol., 2005, vol. 203, no. 1, pp. 27-35.

Sencio, V., Barthelemy, A., Tavares, L.P., et al., Gut dysbiosis during influenza contributes to pulmonary pneumococcal superinfection through altered short-chain fatty acid production, Cell Rep., 2020, vol. 30, no. 9, pp. 2934-2947.

Shahwan, K., Hesse, M., Mork, A.K., et al., Sialic acid binding properties of soluble coronavirus spike (S1) proteins: differences between infectious bronchitis virus and transmissible gastroenteritis virus, Viruses, 2013, vol. 5, no. 8, pp. 1924-1933.

Shepardson, K., Larson, K., Cho, H., et al., A novel role for PDZ-binding motif of influenza A virus nonstructural protein 1 in regulation of host susceptibility to postinfluenza bacterial superinfections, Viral Immunol., 2019, vol. 32 , no. 3 , pp. $131-143$.

Shibata, M., Aoki, H., Tsurumi, T., et al., Mechanisms of uncoating of influenza B virus in MDCK cells: action of chloroquine, J. Gen. Virol., 1983, vol. 64, no. 5, pp. 1149-1156.

Shinya, K., Ebina, M., Yamada, S., et al., Avian flu: influenza virus receptors in the human airway, Nature, 2006, vol. 440, no. 7083, pp. 435-436.

Shivakumar, S., Panigrahi, T., Shetty, R., et al., Chloroquine protects human corneal epithelial cells from desiccation stress induced inflammation without altering the autophagy flux, Biomed. Res. Int., 2018, vol. 2018, art. ID 7627329.

Short, K.R., Kasper, J., van der Aa, S., et al., Influenza virus damages the alveolar barrier by disrupting epithelial tight junctions, Eur. Respir. J., 2016, vol. 47, no. 3, pp. 954-966.

Silvestri, M. and Rossi, G.A., Melatonin: its possible role in the management of viral infections-a brief review, Ital. J. Pediatr., 2013, vol. 39, art. ID 61.

Simmons, G., Zmora, P., Gierer, S., et al., Proteolytic activation of the SARS-coronavirus spike protein: cutting enzymes at the cutting edge of antiviral research, Antiviral Res., 2013, vol. 100, no. 3, pp. 605-614.
Skehel, J., An overview of influenza haemagglutinin and neuraminidase, Biologicals, 2009, vol. 37, no. 3, pp. 177-178.

Sloots, T.P., McErlean, P., Speicher, D.J., et al., Evidence of human coronavirus HKU1 and human bocavirus in Australian children, J. Clin. Virol., 2006, vol. 35, no. 1, pp. 99-102.

Small, C.L., Shaler, C.R., McCormick, S., et al., Influenza infection leads to increased susceptibility to subsequent bacterial superinfection by impairing NK cell responses in the lung, $J$. Immunol., 2010, vol. 184, no. 4, pp. 2048-2056.

Smith, W., Andrewes, C.H., and Laidlaw, P.P., A virus obtained from influenza patients, Lancet, 1933, vol. 222, no. 5732, pp. 66-68.

Smith, E.C., Sexton, N.R., and Denison, M.R., Thinking outside the triangle: replication fidelity of the largest RNA viruses, Ann. Rev. Virol., 2014, vol. 1, no. 1, pp. 111-132.

Sodeman, W.A., Doerner, A.A., Gordon, E.M., and Gillikin, C.M., Chloroquine in hepatic amebiasis, Ann. Int. Med., 1951, vol. 35, no. 2, pp. 331-341.

Sola, I., Almazan, F., Zuniga, S., and Enjuanes, L., Continuous and discontinuous RNA synthesis in coronaviruses, Ann. Rev. Virol., 2015, vol. 2, no. 1, pp. 265-288.

Solomon, V.R. and Lee, H., Chloroquine and its analogs: a new promise of an old drug for effective and safe cancer therapies, Eur. J. Pharmacol., 2009, vol. 625, nos. 1-3, pp. 220-233.

Son, D. and Chung, M.H., In vitro synergism between chloroquine and antibiotics against Orientia tsutsugamushi, Infect. Chemother., 2014, vol. 46, no. 3, pp. 182-188.

Spickler, A.R., Influenza. Flu, grippe, avian influenza, grippe aviaire, fowl plaque, swine influenza, hog flu, pig flu, equine influenza, canine influenza, 2016. http://www.cfsph.iastate.edu/Factsheets/pdfs/influenza.pdf. Accessed April 7, 2020.

Spiekermann, S., Landmesser, U., Dikalov, S., et al., Electron spin resonance characterization of vascular xanthine and $\mathrm{NAD}(\mathrm{P}) \mathrm{H}$ oxidase activity in patients with coronary artery disease, Circulation, 2003, vol. 107, no. 10 , pp. $1383-1389$.

Srinivasan, V., Mohamed, M., and Kato, H., Melatonin in bacterial and viral infections with focus on sepsis: a review, Recent Pat. Endocr., Metab. Immune Drug Discovery, 2012, vol. 6, no. 1, pp. 30-39.

Sritharan, M., Iron and bacterial virulence, Ind. J. Med. Microbiol., 2006, vol. 24, no. 3, pp. 163-164.

Stavrinides, J. and Guttman, D.S., Mosaic evolution of the severe acute respiratory syndrome coronavirus, J. Virol., 2004, vol. 78, no. 1, pp. 76-82.

Steinhauer, D.A., Role of hemagglutinin cleavage for the pathogenicity of influenza virus, Virology, 1999, vol. 258, no. 1, pp. 1-20.

Steinhauer, D.A., de la Torre, J.C., and Holland, J.J., High nucleotide substitution error frequencies in clonal pools of vesicular stomatitis virus, J. Virol., 1989, vol. 63, no. 5, pp. 2063-2071.

Štětinová, V., Herout, V., and Květina, J., In vitro and in vivo antioxidant activity of ambroxol, Clin. Exp. Med., 2004, vol. 4, no. 3, pp. 152-158. 
Sugrue, R.J. and Hay, A.J., Structural characteristics of the M2 protein of influenza A viruses: evidence that it forms a tetrameric channel, Virology, 1991, vol. 180, no. 2, pp. 617-624.

Sun, K. and Metzger, D.W., Influenza infection suppresses NADPH oxidase-dependent phagocytic bacterial clearance and enhances susceptibility to secondary methicillin-resistant Staphylococcus aureus infection, $J$. Immunol., 2014, vol. 192, no. 7, pp. 3301-3307.

Suzuki, A., Okamoto, M., Ohmi, A., et al., Detection of human coronavirus-NL63 in children in Japan, Pediatr. Infect. Dis. J., 2005, vol. 24, no. 7, pp. 645-646.

Szczepanski, A., Owczarek, K., Bzowska, M., et al., Canine respiratory coronavirus, bovine coronavirus, and human coronavirus OC43: receptors and attachment factors, Viruses, 2019, vol. 11, no. 4, art. ID 328.

Tan, D.X., Kormaz, A., Reiter, R.J., and Manchester, L.C., Ebola virus disease: potential use of melatonin as a treatment, J. Pineal Res., 2014, vol. 57, no. 4, pp. 381384.

Tashiro, M., Ciborowski, P., Reinacher, M., et al., Synergistic role of staphylococcal proteases in the induction of influenza virus pathogenicity, Virology, 1987, vol. 157 , no. 2 , pp. $421-430$.

Taubenberger, J.K. and Kash, J.C., Influenza virus evolution, host adaptation and pandemic formation, Cell Host Microbe, 2010, vol. 7, no. 6, pp. 440-451.

Tauber, S.C. and Nau, R., Immunomodulatory properties of antibiotics, Curr. Mol. Pharmacol., 2008, vol. 1, no. 1, pp. 68-79.

Taylor, R.M., Studies on survival of influenza virus between epidemics and antigenic variants of the virus, Am. J. Publ. Health Nat. Health, 1949, vol. 39, no. 9, pp. 171178.

Tektonidou, M.G., Andreoli, L., Limper, M., et al., EULAR recommendations for the management of antiphospholipid syndrome in adults, Ann. Rheum. Dis., 2019, vol. 78, no. 10, pp. 1296-1304.

Terada, L.S., Piermattei, D., Shibao, G.N., et al., Hypoxia regulates xanthine dehydrogenase activity at pre- and posttranslational levels, Arch. Biochem. Biophys., 1997, vol. 348 , no. 1 , pp. 163-168.

Thyagarajan, B. and Bloom, J.D., The inherent mutational tolerance and antigenic evolvability of influenza hemagglutinin, eLife, 2014, vol. 3, p. e03300.

To, E.E., Erlich, J.R., Liong, F., et al., Mitochondrial reactive oxygen species contribute to pathological inflammation during influenza A virus infection in mice, $A n$ tioxid. Redox Signaling, 2020, vol. 32, no. 13, pp. 929942.

Tong, S., Zhu, X., Li, Y., et al., New world bats harbor diverse influenza A viruses, PLoS Pathog., 2013, vol. 9, no. 10, art. ID e 1003657.

Tortorici, M.A., Walls, A.C., Lang, Y., et al., Structural basis for human coronavirus attachment to sialic acid receptors, Nat. Struct. Mol. Biol., 2019, vol. 26, no. 6, pp. 481-489.

Tsai, K.N. and Chen, G.W., Influenza genome diversity and evolution, Microbes Infect., 2011, vol. 13, no. 5, pp. 479-488.

Tseng, Y.T., Wang, S.M., Huang, K.J., et al., Self-assembly of severe acute respiratory syndrome coronavirus mem- brane protein, J. Biol. Chem., 2010, vol. 285, no. 17, pp. 12862-12872.

Tyrrell, D.A. and Bynoe, M.L., Cultivation of viruses from a high proportion of patients with colds, Lancet, 1966, vol. 1, no. 7428, pp. 76-77.

Tyrrell, D.A., Almeida, J.D., Cunningham, C.H., et al., Coronaviridae, Intervirology, 1975, vol. 5, nos. 1-2, pp. 76-82.

Umeki, S., Anti-inflammatory action of gentamycin through inhibitory effect on neutrophil NADPH oxidase activity, Comp. Biochem. Physiol., Part B: Biochem. Mol. Biol., 1995, vol. 110, no. 4, pp. 817-821.

van der Sluijs, K.F., van Elden, L.J., Nijhuis, M., et al., IL-10 is an important mediator of the enhanced susceptibility to pneumococcal pneumonia after influenza infection, $J$. Immunol., 2004, vol. 172, no. 12, pp. 7603-7609.

Varga, Z.T., Ramos, I., Hai, R., et al., The influenza virus protein PB1-F2 inhibits the induction of type I interferon at the level of the MAVS adaptor protein, PLoS Pathog., 2011, vol. 7, no. 6, art. ID e1002067.

Vasin, A.V., Temkin, O.A., Egorov, V.V., et al., Molecular mechanisms enhancing the proteome of influenza A viruses: an overview of recently discovered proteins, Virus Res., 2014, vol. 185, pp. 53-63.

Vincent, M.J., Bergeron, E., Benjannet, S., et al., Chloroquine is a potent inhibitor of SARS coronavirus infection and spread, Virol. J., 2005, vol. 2, no. 1, art. ID 69.

Visher, E., Whitefield, S.E., McCrone, J.T., et al., The mutational robustness of influenza A virus, PLoS Pathog., 2016, vol. 12, no. 8, art. ID e 1005856.

Vivino, F.B., Carsons, S.E., Foulks, G., et al., New treatment guidelines for Sjogren's disease, Rheum. Dis. Clin. North Am., 2016, vol. 42, no. 3, pp. 531-551.

Voronina, T.A., Antioxidant Mexidol: neuropsychotropic effects and action mechanism, Psikhofarmakol. Biol. Narkol., 2001, vol. 1, no. 1, pp. 2-12.

Waqar, T., Khushdil, A., and Haque, K., Efficacy of chloroquine as a first line agent in the treatment of uncomplicated malaria due to Plasmodium vivax in children and treatment practices in Pakistan: a pilot study, $J$. Pak. Med. Assoc., 2016, vol. 66, no. 1, pp. 30-33.

Watanabe, T., Watanabe, S., and Kawaoka, Y., Cellular networks involved in the influenza virus life cycle, Cell Host Microbe, 2010, vol. 7, no. 6, pp. 427-439.

Watanabe, Y., Berndsen, Z.T., Raghwani, J., et al., Vulnerabilities in coronavirus glycan shields despite extensive glycosylation, Nat. Commun., 2020, vol. 11, art. ID 2688. Accessed April 7, 2020.

https://doi.org/10.1038/s41467-020-16567-0

Wertheim, J.O., Chu, D.K.W., Peiris, J.S.M., et al., A case for the ancient origin of coronaviruses, J. Virol., 2013, vol. 87 , no. 12 , pp. 7039-7045.

Wood, P.M., The two redox potentials for oxygen reduction to superoxide, Trends Biochem. Sci., 1987, vol. 12, pp. 250-251.

Wood, P.M., The potential diagram for oxygen at $\mathrm{pH} \mathrm{7,}$ Biochem. J., 1988, vol. 253, no. 1, pp. 287-289.

Wu, W., Li, R., Li, X., et al., Quercetin as antiviral agent inhibits influenza A virus (IAV) entry, Viruses, 2015, vol. 8, no. 1, art. ID e6. 
Xue, G., Gong, L., Yuan, C., et al., A structural mechanism of flavonoids in inhibiting serine proteases, Food Funct., 2017, vol. 8, no. 7, pp. 2437-2443.

Yamamoto, N., Matsuyama, S., Hoshino, T., and Yamamoto, N., Nelfinavir inhibits replication of severe acute respiratory syndrome coronavirus 2 in vitro, bioRxiv, 2020.

https://doi.org/10.1101/2020.04.06.026476

Yamaya, M., Nishimura, H., Nadine, L.K., et al., Ambroxol inhibits rhinovirus infection in primary cultures of human tracheal epithelial cells, Arch. Pharm. Res., 2014, vol. 37, no. 4, pp. 520-529.

Yan, Y., Zou, Z., Sun, Y., et al., Anti-malaria drug chloroquine is highly effective in treating avian influenza A H5N1 virus infection in an animal model, Cell Res., 2013, vol. 23, no. 2, pp. 300-302.

Yang, B., Yao, D.F., Ohuchi, M., et al., Ambroxol suppresses influenza-virus proliferation in the mouse airway by increasing antiviral factor levels, Eur. Respir. J., 2002, vol. 19, no. 5, pp. 952-958.

Yin, Y. and Wunderink, R.G., MERS, SARS and other coronaviruses as causes of pneumonia, Respirology, 2018, vol. 23, no. 2, pp. 130-137.

York, I.A., Stevens, J., and Alymova, I.V., Influenza virus $\mathrm{N}$-linked glycosylation and innate immunity, Biosci. Rep., 2019, vol. 39, no. 1, art. ID BSR20171505.

Yoshimura, A. and Ohnishi, S., Uncoating of influenza virus in endosomes, J. Virol., 1984, vol. 51, no. 2, pp. 497-504.
Zakaryan, H., Arabyan, E., Oo, A., and Zandi, K., Flavonoids: promising natural compounds against viral infection, Arch. Virol., 2017, vol. 162, no. 9, pp. 25292551.

Zhang, R., Wang, X., Ni, L., et al., COVID-19: melatonin as potential adjuvant treatment, Life Sci., 2020, vol. 250, art. ID 117583 .

Zhao, Q., Li, S., Xue, F., et al., Structure of the main protease from a global infectious human coronavirus, HCoV-HKU1, J. Virol., 2008, vol. 82, no. 17, pp. 8647-8655.

Zhao, P., Sun, L., Xiong, J., et al., Semiaquatic mammals might be intermediate hosts to spread avian influenza virus from avian to human, Sci. Rep., 2019, vol. 9, no. 1, art. ID 11641.

Zheng, J., Yamada, Y., Fung, T.S., et al., Identification of $\mathrm{N}$-linked glycosylation sites in the spike protein and their functional impact on the replication and infectivity of coronavirus infectious bronchitis virus in cell culture, Virology, 2017, vol. 513, pp. 65-74.

Zolotov, N.N., Smirnov, L.D., Kuz'min, V.I., et al., Derivatives of 3-hydroxypyridine as inhibitors of proteolytic enzymes, Khim.-Parm. Zh., 1989, vol. 23, no. 2, pp. 133-135.

Zumla, A., Chan, J.F., Azhar, E.I., et al., Coronavirusesdrug discovery and therapeutic options, Nat. Rev. Drug Discovery, 2016, vol. 15, no. 5, pp. 327-347.

Translated by A. Ostyak 